\title{
Domestic Resource Mobilization and Human Capital Development in Sub- Saharan Africa
}

Received: 23.07.2021

Oluwatosin Adeniyi", Mutiu A. Oyinlola*, and Abdulfatai A. Adedeji*

\section{Abstract}

This study investigates the nexus between domestic resource mobilization using aggregated and disaggregated taxes, and human capital accumulation as measured by the index of human capital and total factor productivity. The study explores panel Autoregressive Distributed Lag. We further explore the linear and nonlinear effects of taxes on human capital accumulation. The results from the scatterplots show that taxes at aggregate and disaggregated levels positively correlated with the two measures of human capital. On the linear analysis, the impact of aggregated and disaggregated taxes is largely negative under the index of human capital but largely positive under the second measure in the short-run. However, the long-run results indicate that aggregate and disaggregated taxes significantly amplify human capital accumulation. On nonlinearity, there is no presence of human capital laffer curve (HCLC) in the short-run under the two measures of human capital. However, there is presence of HCLC in the long-run. The net effects results show that some taxes (such as indirect taxes, taxes on goods and services) are distortionary in improving the level of human capital development while some taxes (such as total tax, direct tax, taxes on income, profit, and gains) can distort human capital development in the SSA region.

Keywords: Domestic Resource Mobilization, Human Capital, PARDL, Net Effects, SSA

$$
\text { JEL: H2O, G50 }
$$

\section{Introduction}

The importance of human capital in an economy cannot be overemphasized. In recent years, sub-Saharan Africa (SSA) has made efforts in maintaining consistent positive economic growth. Given the enormous developmental challenges (such as high unemployment rate, high poverty level, and income inequality, among others) facing the region, human capital accumulation has been identified as a key driver for the region to develop especially in terms of quality. Also, available evidence has shown that human capital is a crucial component of national wealth or economic prosperity (Trostel, 1993). More evidence has also shown that human capital development is essential to and economic development (Davies and Whalley,

\footnotetext{
Department of Economics, University of Ibadan
} 


\section{Articles}

1989; Raheem et al., 2018; Oyinlola et al., 2020). Despite the critical role of human capital development, most SSA countries have been facing enormous challenges in addressing human capital gaps.

The Global Human Capital Report by Samans et al. (2017) shows that subSaharan Africa has the highest human capital development gaps in the world. Specifically, SSA has 47 percent human capital development gaps compared to North America and Western Europe with 20 percent and 33 percent, respectively. This points to the fact that almost half of the human capital potentials are not engaged in productive activities. By implication, this undermines the expansion of the region's economic prosperity as well as creating more social problems for the region. More so, the region recorded the lowest literacy rate ${ }^{1}$ of 60.9 percent relative to Europe and Central Asia and Latin America and the Caribbean with 99 percent and 92.6 percent, respectively, in 2010. This huge disparity should be of great concern for the countries in the region. Further evidence reveals that an estimated 89 million youths in 2015 (between ages 12 and 24 years) are out of school in Sub-Saharan Africa. This disturbing outcome is projected to rise by an estimated 40 million more youth in the next decade $^{2}$. These potential human resources will be exposed to face an uncertain future without adequate work and life skills.

Further, the paucity of resources has greatly affected the region's ability to invest heavily in human capital development. Evidently, advanced economies have invested huge resources (mostly derived from domestic sources) in human capital development. There are many competitive developmental needs for the SSA region to address but the capacity to explore domestic resource mobilization has been very poor. This in a way largely affects investment in human capital development in the region. In most developed countries, huge domestic resource mobilization from tax avails the countries the chance to generate huge revenue for human capital investment. However, SSA remains behind inadequately exploring its tax system to raise more resources for the development of its human capital. According to ICTD/UNUWIDER (2017), the SSA region is the lowest tax collector in the world. The poor domestic resource mobilization (i.e. tax) continues to slow the progress of the region. For instance, the average tax-to-GDP ratio $^{3}$ for SSA countries in 2016 was about 15 percent relative to advanced economies and OECD countries with about 27 percent and 34.3 percent, respectively. This may partly explain the huge financing gap for human capital development in the region. Other seemingly easy sources ${ }^{4}$ of finance have proven to be ineffective in maintaining human capital investment as evident in their unstable growth patterns in the region.

In the literature, several studies have examined the role of human capital in growth in SSA which includes Gyimah-Brempong and Wilson (2004); Gyimah-Brempong et al. (2006); Mobolaji (2010); Raheem et al. (2018), Oyinlola and Adedeji (2019), among others. However, studies on the relationship between domestic resource mobilization (i.e. tax) and human capital are very scanty with respect

\footnotetext{
${ }^{1}$ https://ourworldindata.org/literacy

2 https://www.worldbank.org/en/topic/education/publication/out-of-school-youth-in-sub-saharan-africa

${ }^{3}$ IMF Regional Economic Outlook (2018) and OECD Revenue Statistics (2017)

${ }^{4}$ Natural resource rents, debt, FDI among others
} 


\section{Articles}

to the region. Thus, the study contributes to the literature by exploring this huge gap. In essence, it gives a detailed empirical examination of the extent to which domestic resource mobilization influences human capital development in SSA. Specifically, the study explores aggregate tax and disaggregated to capture domestic resource mobilization while human capital is measured at a quality level. This is to ascertain if this financing option has the potential to improve resources devoted to human capital development in the region. More importantly, this huge exploration is critical for the region's development especially its policy relevance. More so, the study tests for the nonlinear effect of tax on human capital at aggregate and disaggregated levels ('Human Capital Laffer Curve'-HCLC). This allows us to determine if the optimal tax level is required when raising revenue to reduce the distortionary effects associated with some taxes.

The study deploys complete data on 14 sub-Saharan countries between 1990 and 2017. To account for short-run and long-run impacts, Panel Autoregressive Distributed Lag (PARDL) is explored. The rest of the paper is structured as follows. Section two captures a brief literature review. Also, section three deals with theoretical and methodological issues. In the fourth section, empirical results and discussions are presented. The final section focuses on the conclusion and policy implications.

\section{Brief Literature Review}

There is mounting evidence of the role of human capital and economic growth across countries and regions from theoretical and empirical standpoints. However, this study limits the synopsis of the literature to tax as a key driver of human capital.
Domestic Resource Mobilization and Human Capital

Development in Sub-Saharan Africa

Starting with the measurement issue, there is no unanimous agreement among scholars on a particular indicator for human capital. The empirical studies that have utilized education include Adeniyi et al (2020), Oyinlola and Adedeji (2019), Kotaskova et al. (2018), Nowak and Dahal (2016), Benos and Zotou (2014), and Barro (2013), among others. In addition to education, some studies have also explored education and health indicators as enabling factors. This can be found in the works of Bloom et al. (2004), Gyimah-Brempong and Wilson (2004), Weil (2007), Hatwig (2010), and Ogundari and Awokuse (2018), and $\mathrm{Li}$ and Liang (2010). Additionally, studies have explored the index of human capital and total factor productivity (see Adeniyi et al., 2020; Oyinlola, 2019). All these measures of human capital have played a prominent role in the growth process.

In the literature, the tax has been identified as a key financing source for raising resources to fund investments such as human capital across the world. More so, the important roles of tax in human capital development have been documented in the literature. From a theoretical perspective, it has been established that a huge investment in human capital is critical for overall development (Romer, 1986; Mankiw et al., 1992). Thus, the greater number of resources devoted to building human capacity through an increase in knowledge and skills determine the rate at which countries/regions accumulate human capital.

Furthermore, taxation plays a significant role in mobilizing resources for the development of human capital. More so, the literature on human capital has argued for the relationship between tax and human capital development. However, the effect of tax on human capital depends on the tax 


\section{Articles}

system and policy formulation utilized by individual countries. Several studies have also examined the relationship between tax and human capital and different conclusions were derived. In the study of Hendricks (2001) on the effect of taxes on human capital, moving to a proportional tax induces a substantial polarization of educational attainment as highability workers attend college more frequently, while low-ability workers reduce their college attendance. Therefore, the lifetime earnings inequality, which is measured by the quintile ratio, increases by $18.3 \%$. However, the effects on intergenerational mobility are small, suggesting that concerns about equality of opportunity may be unfounded.

Moreover, it was demonstrated by Kaplow (1994) that the effect of an income tax on human capital significantly deviates from the conventional and proposed income tax treatments of wages and education. However, conventional income tax is closer to a generally acknowledged consumption tax because individuals' primary asset of human capital receives treatment close to that dictated by a consumption tax. Studies by Jacobs and Bovenberg (2010) indicated that a dual income tax with a positive marginal tax rate on both labor income and capital income is optimal. They further expatiated that the optimal marginal tax rate on capital income is lower than that on labor income based on the elasticity of savings as compared to investment in human capital. Also, Heckman et al. (1999) explained that conventional partial equilibrium approaches present an overly optimistic view of what tax and tuition policy can achieve because of the change in human capital investment levels which is induced by the change in prices due to the policy. Moreover, conventional partial equilibrium approaches fail to provide an accurate assessment of the welfare consequences of these policies.

Exploring the role of income taxation and finite horizons in a human capital model, Echevarria and Iza (2000) revealed several findings in their study. First, the size of the tax revenue required strongly affects the optimal (the welfare-maximizing) capital-labor income tax portfolio. Second, a zero physical capital income tax rate need not be optimal. Third, how the finite life cycle is split between the working and the retirement period also matters. And lastly, the size of the externality in the human capital production also affects the optimal income tax rate mix.

A study on welfare-maximizing tax structure in a model with human capital was examined by Gomez (2000) and his simulation results strongly suggested that higher reliance on consumption taxation would increase welfare. Under the benchmark parameterization of the model by Pecorino (1995) in tax rates and tax revenues in a model of growth through human capital accumulation, the growth-reducing effects of taxation are found to have a moderate, but significant effect in lowering the revenue-maximizing rate of taxation relative to a static model. Moreover, tax avoidance can either increase or reduce economic growth and this depends on the value of the nominal tax rate and on the avoidance intensity, which is the productivity of human capital in avoiding taxes (Freire-Serén and Martí, 2013).

Another study by Bovenberga and Ewijk (1997) demonstrated that progressive taxes impede long-run growth in their study of Progressive taxes, equity, and human capital accumulation in an endogenous growth model with overlapping generations. Also, it exacerbates distortions associated with intergenerational spillovers. However, these taxes strengthen the net foreign asset position 


\section{Articles}

by raising savings. Davies et al. (2000) explained in their study on consumption and income taxes that consumption taxation is better than labor income taxation for public provision of goods except for educational investment. However, where subsidies are feasible for observed education investment, the consumption tax rate is independent of the degree of observability but as the subsidy rate is higher, the lower is the observability. He further explained that optimal tax rates for goods that provide consumption and education investment simultaneously are below normal rates for observed pure consumption.

In sum, these studies suggested that taxes can influence the level of human capital depending on the nature of the tax. However, there is little evidence to explain the role of tax in developing regions such as the SSA region. More so, these studies do not test for the nonlinear effect of tax on human capital. This is essential to determine if there is a need for optimal tax in the relationship between tax and human capital. Thus, this study provides evidence on the relationship between tax and human capital in the SSA region on one hand and testing for nonlinear effects in the relationship on the other hand.

\section{Theoretical Framework and Methodology}

\subsection{Theoretical Framework}

The importance of human capital has been discussed extensively in the new growth theory. Thus, endogenous growth models have emphasized the accumulation of human capital for meaningfully productive activities in an economy. The acquisition of human capital by labour is different from abstract knowledge. Human capital captures the abilities, skills, and knowledge possessed
Domestic Resource Mobilization and Human Capital

by workers. Since conventional goods are characterized by rivalry and excludability, human capital also possesses these features. In essence, the human capital model under endogenous growth models is similar to the Solow, Ramsey, and Diamond models due to the assumption of constant returns to scale. However, moderate changes in resources allocated to human capital translate to huge changes in output per worker. This suggests that human capital accumulation can only occur when more resources are invested in it.

More so, this potentially explains the large differences across countries' incomes. Some countries or regions mobilized resources from different sources (such as tax, loans, natural resources, personal remittances, among others) to promote human capital by increasing the abilities, skills, and knowledge of workers to contribute efficiently and innovatively in the production process. Earnings from workers show acquired skills rather than intrinsic abilities. Hence, understanding the accumulation of human capital suggests that the share of income devoted to human capital can be increased. The process of accumulating human capital resembles physical capital accumulation processes.

Specifically, an increase in the amount of resources devoted to human capital increases the output produced in the future. Theoretically, this implies that investment in human capital is very crucial for any significant improvement in output (Schultz, 1961 \& 1971). In the endogenous growth model, human capital accumulation is modelled similarly to physical capital accumulation as presented below.

$\dot{H}(t)=s_{H} Y(t)$ 


\section{Articles}

Where $S_{H}$ is the fraction of resources allocated to human capital accumulation. Hence, this model demonstrates the connection between resources and human capital.

\subsection{Methodology}

\subsubsection{Model Specification}

The theoretical foundation above shows that human capital accumulation relied heavily on the amount of resources devoted to it. Hence, an increase in the abilities, skills, and knowledge of workers required huge investments. Taking a cue from the simple model in equation (1) as proposed by Romer (1990), the role of domestic resources mobilization through taxation in human capital accumulation is presented in equation (2) as follows:

$$
\begin{aligned}
H U M_{i t}= & \beta_{0}+\beta_{1} D O M_{i t}+ \\
& +Z_{i t} \delta+\mu_{i}+\pi_{i t}
\end{aligned}
$$

Where $H U M_{i t}$ is the human capital measure. Human capital accumulation is embedded in the stock of knowledge and skills that workers possessed to perform efficiently and effectively in the production process (Sheffrin, 2003). In this study, we explore the log of total factor productivity and index of human capital (in log form) to capture the quality of human capital development. These measures have been explored in the literature to explain the quality of human capital (see Adeniyi, et al., 2020; Oyinlola and Adedeji, 2019; Jajri, 2007; Miller and Upadhyay, 2002). The number of countries is captured by $\mathrm{i}=1, \ldots, \mathrm{N}$; the year is captured by $\mathrm{t}=1, \ldots$, $\mathrm{T} ; \mu_{i}$ is the country-specific effect; $\pi_{i t}$ is the disturbance term. $D O M_{i t}$ represents domestic resource mobilization. Theoretically, an increase in resources allocated to human capital increases the skills and knowledge acquired by workers in an economy. Domestic resource mobilization is represented by aggregate and disaggregated taxes. The importance of taxation has been documented in the literature as a crucial financing option through which government raises revenue domestically, to finance the public investment as well as improve the quality of human capital development (Barro, 1990; Bleaney et al., 2001; Ehrhart et al., 2014; Atems, 2015). Taxes are associated with externalities (positive and negative). However, this study posits that government can mobilize resources through taxes to increase investment in human capital. In other words, the effort of the government to raise required revenue from tax determine largely the level of human capital accumulation in a country or region. Thus, we explore total taxes, indirect and direct taxes (forms) as well as its subforms such as taxes on income, profit and capital gains, taxes on goods and services, and taxes on international trade. $Z_{i t}$ is a $K \times 1$ vector of control variables. Many variables have been documented in the literature as fundamental drivers of human capital. These variables are credit to the private sector, foreign direct investment, the log of GDP per capita, government final consumption, and trade openness. The role of the financial sector (credit to the private sector) in human capital accumulation 


\section{Articles}

is essential. As argued by Oyinlola and Adedeji (2019), Ho and lyke (2017), and Dutta and Mukherjee (2017), the financial sector provides resources for investment to thrive (in our case, human capital accumulation). Foreign direct investment plays a significant role in human capital accumulation through spillover effects. Foreign direct investment facilitates the transfer of knowledge and skills (Michie, 2001 and Li and Liu, 2005). GDP per capita measures the level of income per person. Theoretically, the level of income of an individual determines largely the extent to which he/she can acquire more skills and knowledge (see Romer, 1990). Government final consumption measures the role of the public sector in human capital accumulation (see Arpaia and Turrini, 2008) while trade openness represents the level of receptiveness to foreign trade which can facilitate knowledge spillover (Law and Habibulllah, 2009; Zahonogo, 2017). It is also important to account for the role of nonlinearity between tax and human capital accumulation. Mounting evidence from the literature has shown that there is always an optimal level of tax that can maximize public investment (see Barro, 1990; Ehrhart et al., 2014). Hence, this study tests for optimal tax levels in the case of human capital. This is termed the 'Human Capital Laffer Curve' in our study. Hence, the nonlinear form of equation (2) is presented as follows:

$$
\begin{aligned}
H U M_{i t} & =\beta_{0}+\beta_{1} D O M_{i t}+ \\
& +\beta_{1} D O M_{i t}^{2}+Z_{i t} \delta+\mu_{i}+\pi_{i t}
\end{aligned}
$$

Domestic Resource Mobilization and Human Capital

Development in Sub-Saharan Africa

Where $D O M_{i t}^{2}$ represents the nonlinear relationship between tax and human capital accumulation.

\subsubsection{Estimation Technique}

\section{(a) The Panel Unit Root Tests}

Before exploring panel Autoregressive Distributed Lags (PARDL), it is conventional to conduct panel unit root tests for macro panels with large $T$ to ascertain whether our series are integrated of order zero, $I(0)$, or order one, I(1). Since non-stationarity is a critical issue, it is essential to rely on the dynamic heterogeneous panel data model. Hence, this study employed three different types of panel unit root test. Specifically, panel unit root tests with the null hypothesis of unit root with a common process (Harris and Tzavalis, 1999; Breitung, 2001; Levin, Lin, and Chu, 2002 tests), the unit root with individual unit root process (Im, Pesaran, and Shin., 2003; Maddala and Wu, 1999 tests) and no unit root with common unit root process (Hadri, 2000 Lagrange Multiplier test). Given their specific hypotheses and test regressions, the literature has classified panel unit root into two categories. The following panel unit root tests: Harris and Tzavalis, 1999; Breitung, 2001, Levin, Lin and Chu, 2002, Im, Pesaran, and Shin., 2003; Maddala and Wu, 1999 are classified as non-stationarity tests while Hadri (2000) is classified as stationarity test.

\section{(b) Pooled Mean Group Estimator (PMG)}

The utilisation of pooled dynamic heterogeneous for this study is attributed to the common challenges with static model and dynamic model (Generalised Method of Moments-GMM) in providing consistent estimates in large samples. The asymptotics of conventional large $N$, small $T$ dynamic panel 


\section{Articles}

models are not the same as asymptotics of Large $N$, large $T$ (Blackburne and Frank, 2007). Moreover, small T panel models usually explored fixed-effects or random-effects estimators, or instrumental-variable estimators such as GMM developed by Arellano and Bond (1991). According to Blackburn and Frank (2007), the assumption of homogeneous slope parameters for panel models with large $N$, large $T$ is invalid. Since there is a challenge with a homogeneous dynamic model for all units, it is problematic to assume that longrun parameters are homogenous (Pesaran and Smith, 1995). Thus, Peseran et al. (1999) proposed different estimation techniques for dynamic heterogeneous panel data models which include the Pooled Mean Group (PMG), dynamic fixed-effects (DFE), and Mean Group (MG) estimators. The MG estimator proposed estimation based on $N$ time-series regressions and averaging the estimates while the PMG estimator combines pooling and averaging of coefficients (Pesaran et al., 1999; Blackburne and Frank, 2007). More so, PMG provides efficient pooled estimation by circumventing associated problems with the heterogeneous dynamic estimator compared to MG. Panel models with individual effects may provide inconsistent and invalid results arising from bias generated by the correlation between disturbance term and meandifferenced regressors. This bias issue can be addressed by large $T$ but not through large N. Also, several studies (such as Pesaran and Shin, 1999; Peseran, 1997; Peseran and Smith, 1995) have shown that under several assumptions, long-run estimates derived from Ordinary Least Squares (OLS) regressions are consistent and where a variable is of I (1), the estimate is super-consistent. In the presence of serial correlation, relevant modification of lag orders of the PARDL model is adequate to address serial correlation and regressor endogeneity (Kanas and Kouretas, 2005). Moreover, Pesaran et al. (1999) argued that $P M G$ is a maximum likelihood estimator where the long-run parameters are recovered from a nonlinear form of the short-run parameters. The choice for the PMG is further supported by the Hausman test. Hence, our equations 2 and 3 are modelled in the PARDL framework as follows:

$\Delta H U M_{i t}=\delta_{0 i}+\delta_{1 i} H U M_{i, t-1}+\delta_{2 i} D O M_{i, t-1}+Z_{i, t-1}{ }^{\prime} \delta_{3 i}+\sum_{j=1}^{K 1} \phi_{i j} \Delta H U M_{i, t-j}+$

$\sum_{j=0}^{K 2} \gamma_{i j} \Delta D O M_{i, t-j}+\sum_{j=0}^{K 3} \Delta Z_{i, t-j}{ }^{\prime} \theta_{i j}+\mu_{i}+\pi_{i t}$

$\Delta H U M_{i t}=\delta_{0 i}+\delta_{1 i} H U M_{i, t-1}+\delta_{2 i} D O M_{i, t-1}+Z_{i, t-1}{ }^{\prime} \delta_{3 i}+\delta_{4 i} D O M_{i, t-1}^{2}+\sum_{j=1}^{K 1} \phi_{i j} \Delta H U M_{i, t-j}+$

$\sum_{j=0}^{K 2} \gamma_{i j} \Delta D O M_{i, t-j}+\sum_{j=0}^{K 3} \Delta Z_{i, t-j}{ }^{\prime} \theta_{i j}+\sum_{j=0}^{K 4} \alpha_{i j} \Delta D O M_{i, t-j}^{2}+\mu_{i}+\pi_{i t}$

$i=1,2,3, \ldots, N ; \quad t=1,2,3, \ldots, T$ 
Where $\phi_{i j} \gamma_{i j} \theta_{i j}$ and $\alpha_{i j}$ are short-run The error correction version of equations parameters while $\delta_{1 i}, \delta_{2 i}, \delta_{3 i}$ and $\delta_{4 i}$ are longrun parameters.

4 and 5 is presented as follows:

$$
\begin{aligned}
& \Delta H U M_{i t}=\delta_{1 i}\left[H U M_{i, t-1}-\left(-\frac{\delta_{2 i}}{\delta_{1 i}}\right) D O M_{i, t-1}-Z_{i, t-1}{ }^{\prime}\left(-\frac{\delta_{3 i}}{\delta_{1 i}}\right)\right]+\sum_{j=1}^{K 1} \phi_{i j} \Delta H U M_{i, t-j}+ \\
& \sum_{j=0}^{K 2} \gamma_{i j} \Delta D O M_{i, t-j}+\sum_{j=0}^{K 3} \Delta Z_{i, t-j}{ }^{\prime} \theta_{i j}+\mu_{i}+\pi_{i t}
\end{aligned}
$$

$$
\begin{aligned}
& \Delta H U M_{i t}=\delta_{1 i}\left[H U M_{i, t-1}-\left(-\frac{\delta_{2 i}}{\delta_{1 i}}\right) D O M_{i, t-1}-Z_{i, t-1}\left(-\frac{\delta_{3 i}}{\delta_{1 i}}\right)+\left(-\frac{\delta_{4 i}}{\delta_{1 i}}\right) D O M_{i, t-1}^{2}\right]+\sum_{j=1}^{K 1} \phi_{i j} \Delta H U M_{i, t-j}+ \\
& \sum_{j=0}^{K 2} \gamma_{i j} \Delta D O M_{i, t-j}+\sum_{j=0}^{K 3} \Delta Z_{i, t-j} \theta_{i j}+\sum_{j=0}^{K 4} \alpha_{i j} \Delta D O M_{i, t-j}^{2}+\mu_{i}+\pi_{i t}
\end{aligned}
$$

Where

$$
\begin{aligned}
E C M_{i t-1}= & H U M_{i, t-1}-\rho_{1} \text { DOM }_{i, t-1} \\
& -Z_{i, t-1} \rho_{2}
\end{aligned}
$$

$$
\begin{aligned}
E C M_{i t-1}= & H U M_{i, t-1}-\rho_{1} D O M_{i, t-1}- \\
& -Z_{i, t-1}{ }^{\prime} \rho_{2}+\rho_{3} D^{2} M_{i, t-1}^{2}
\end{aligned}
$$

Where

$$
\rho_{1}=-\frac{\delta_{2 i}}{\delta_{1 i}} ; \quad \rho_{2}=-\frac{\delta_{3 i}}{\delta_{1 i}} ; \rho_{3}=-\frac{\delta_{3 i}}{\delta_{1 i}}
$$

Equations (4') and (5') can be rewritten in the PARDL-ECM framework as follows:

$\Delta H U M_{i t}=\sigma E C M_{i t-1}+\sum_{j=1}^{K 1} \phi_{i j} \Delta H U M_{i, t-j}+\sum_{j=0}^{K 2} \gamma_{i j} \Delta D O M_{i, t-j}+\sum_{j=0}^{K 3} \Delta Z_{i, t-j}^{\prime} \theta_{i j}+\mu_{i}+\pi_{i t}$

$$
\Delta H U M_{i t}=\omega E C M_{i t-1}+\sum_{j=1}^{K 1} \phi_{i j} \Delta H U M_{i, t-j}+\sum_{j=0}^{K 2} \gamma_{i j} \Delta D O M_{i, t-j}+\sum_{j=0}^{K 3} \Delta Z_{i, t-j}{ }^{\prime} \theta_{i j}+\sum_{j=0}^{K 4} \alpha_{i j} \Delta D O M_{i, t-j}^{2}+\mu_{i}+\pi_{i t}
$$

The $E C M_{i t-1}$ captures the long-run equilibrium in the panel ARDL in equations (6 \& 7) and their associated parameters ( $\sigma$ and $\omega)$ represent the speed of adjustment term that shows the period it takes the system to converge to its steady-state when there is any shock. In addition, it is necessary to ascertain the overall effects of taxes in human capital development since equation 5 is a quadratic regression. Thus, the study explores the net effects approach in the literature (see, Asongu and Odhiambo, 2020a \& 2020b; Boateng et al., 2018; Brambor et al., 2006). The net effects are computed as follows:

$$
N E=\left[2 \times\left(C E_{t a x^{2}} \times A V_{t a x}\right)+U C E_{t a x}\right](8)
$$




\section{Articles}

Where $N E$ represents net effects; $C E_{t a x^{2}}$ is the conditional effect of enhancing tax in human capital development (i.e., the estimated parameter); $A V_{\text {tax }}$ is the average value of tax; $U C E_{t a x}$ is the unconditional effect of tax (i.e., the estimated coefficient). The constant (2) is obtained from the quadratic derivation. The net effects are computed for both short-run and long-run periods.

\subsubsection{Data Issues}

The study covers the period between 1990 and 2017 for 14 sub-Saharan African countries. These countries include Benin, Burkina Faso, Cameroon, Central Africa Republic, Eswatini, Kenya, Mauritius, Mozambique, Namibia, Rwanda, Senegal, Sierra Leone, South Africa, and Zimbabwe. The countries are chosen based on tax mobilization efforts through tax-to-GDP ratio (low-less than 10\%, moderate- $10 \%-<15 \%$, and high->15\%-30\%) and availability of data for the key variables of interest. Tax-to-GDP ratios are captured at aggregate and disaggregated levels. These are total tax (TT); direct taxes (DT) and indirect tax (IT); taxes on income, profit, and capital gains (IPC), taxes on goods and services (TGS), and taxes on international trade (TIT). All are measured as a percentage of GDP and sourced by International Centre for Tax and Development (2019). Human capital indicators as captured by the index of human capital (HC) and total factor productivity (TFP) are sourced by Penn World Table (Version 9.1). Data for all the control variables which include credit to the private sector as a percentage of GDP (CRE), foreign direct investment as a percentage of GDP (FDI), GDP per capita, constant 2011, US\$ (GDPPC)-, government final consumption as a percentage of GDP (GOVT), and trade openness-ratio of trade-to-GDP (TOP) are sourced by World Development Indicators (2019).

\section{Empirical Result and Discussion}

\subsection{Preliminary Analysis}

As the standard procedures for variables with time series characteristics, the study starts by examining the statistical features of all the series explored in our models. Table 1 presents the summary statistics of all series. The mean value shows that the index of human capital is relatively high among human capital indicators. However, total factor productivity appears to be less volatile among the indicators. On domestic resource mobilization indicators, total tax and indirect tax are relatively high while taxes on income, profit, and capital gains are the lowest. The average value of the total tax indicates that there is an improvement in domestic resource mobilization in the SSA region but still very low compared to OECD countries. In terms of volatility as measured by standard deviation, taxes on goods and services are more stable compared to others. To a larger extent, domestic resource mobilization is relatively stable among the countries in the region. Overall, GDP per capita is relatively higher among all the series while total factor productivity is the lowest. Moreover, the former is more volatile whereas the latter is less volatile among the series. 
Table 1: Summary Statistics

\begin{tabular}{|l|c|c|c|c|c|}
\hline \multicolumn{1}{|c|}{ VARIABLE } & Obs. & Mean & Std. Dev. & Min & Max \\
\hline HC & 392 & 1.702 & 0.431 & 1.030 & 2.809 \\
\hline TFP & 392 & 0.504 & 0.236 & 0.099 & 1.242 \\
\hline TT & 392 & 15.803 & 6.656 & 2.143 & 33.753 \\
\hline DT & 392 & 5.587 & 3.783 & 0.490 & 16.534 \\
\hline IT & 392 & 10.217 & 4.021 & 1.244 & 24.288 \\
\hline IPC & 392 & 5.329 & 3.774 & 0.490 & 17.128 \\
\hline TGS & 392 & 6.170 & 2.685 & 0.630 & 13.814 \\
\hline TIT & 392 & 3.882 & 3.707 & 0.172 & 23.462 \\
\hline CRE & 392 & 29.104 & 33.894 & 1.604 & 160.125 \\
\hline FDI & 392 & 2.394 & 4.505 & -2.739 & 39.456 \\
\hline GDPPC & 392 & $1,638.35$ & $2,008.65$ & 126.96 & $10,484.91$ \\
\hline GOVT & 392 & 65.673 & 29.723 & 19.684 & 175.798 \\
\hline TOP & & & & 2.047 & 26.720 \\
\hline
\end{tabular}

Source: Authors' computation. Total tax (TT); direct taxes (DT); indirect tax (IT); taxes on income, profit, and capital gains (IPC), taxes on goods and services (TGS), and taxes on international trade (TIT). All are measured as a percentage of GDP. Index of human capital (HC); total factor productivity (TFP); credit to the private sector as a percentage of GDP (CRE); foreign direct investment as a percentage of GDP (FDI), GDP per capita (GDPPC); government final consumption as a percentage of GDP (GOVT), and trade openness (TOP).

As a precondition for macro panels with large $T$, we carry out panel unit root tests on the variables employed in our estimated models. This is very important due to the concern of non-stationarity associated with this type of macro panel data model. These tests are examined at level and first difference. As presented in Table 2, the first category focuses on panel unit toot tests with null hypothesis of unit root with common process. The result indicates that all the series are integrated of order zero, I(O) except log of GDP per capita (LGDPPC). However, all the series are statistically significant and integrated of order one, I(1). Under the second category (unit root with individual unit root process), most of the variables are statistically significant after the first-differenced. In the third category, all the variables are statistically significant at level. However, the results of explanatory variables are mixed across the three categories suggesting non-stationarity but statistically significant after first-differencing. These results further justify the suitability of PARDL as an appropriate modelling technique for this study. 


\section{Articles}

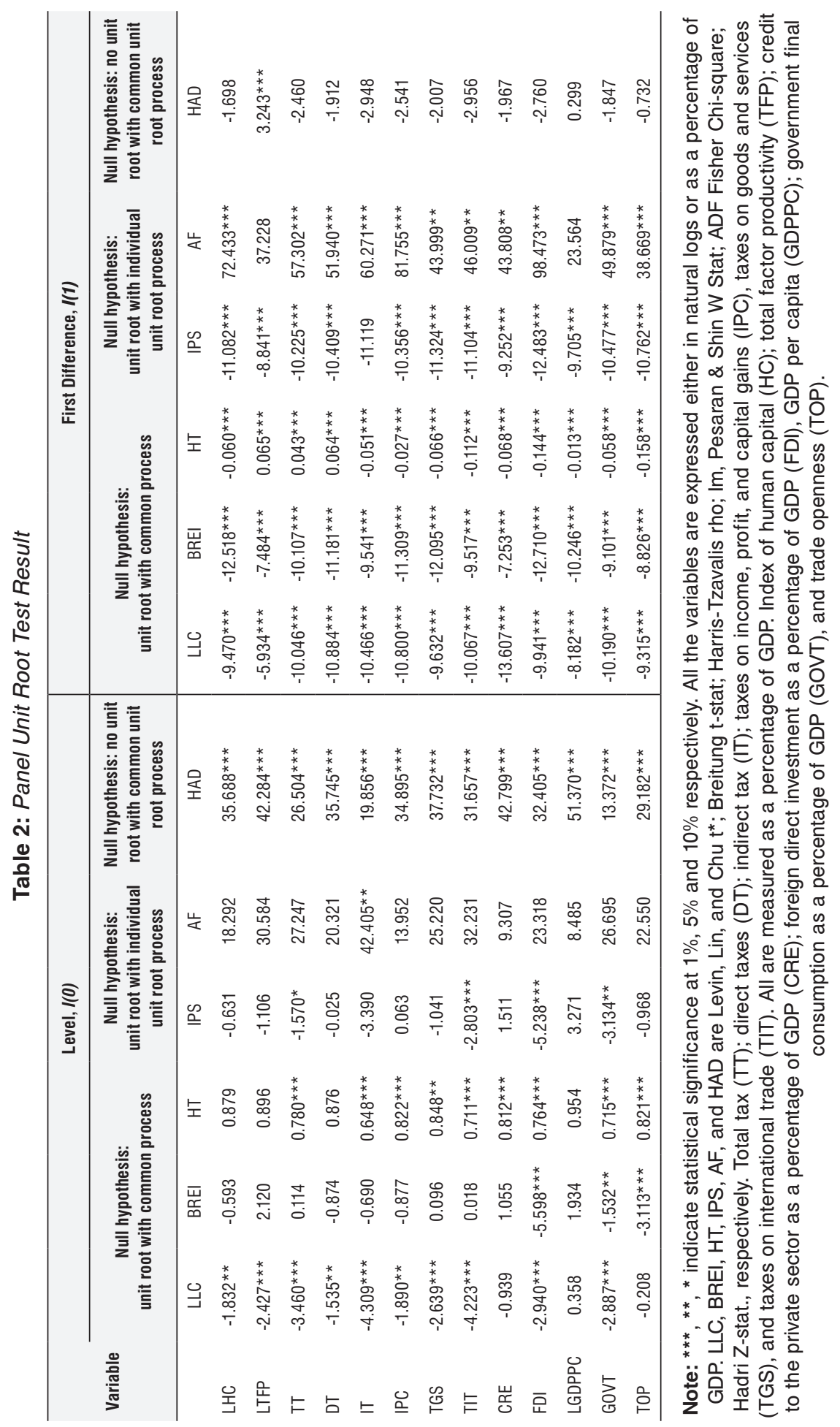


Before our impact analysis, we examine the relationship between domestic resource mobilisation indicators and human capital measures as presented in figures 1-6. The results show largely a positive correlation between measures of domestic resource mobilization and human capital accumulation. However, the relationship is slightly positive for taxes on international trade and index of human capital, and taxes on goods and services, and total factor productivity. From the results, there is an indication that SSA countries can boost human capital development by efficiently mobilizing resources domestically through their tax structures. Thus, we can conclude that domestic resource mobilization is human capital-enhancing.

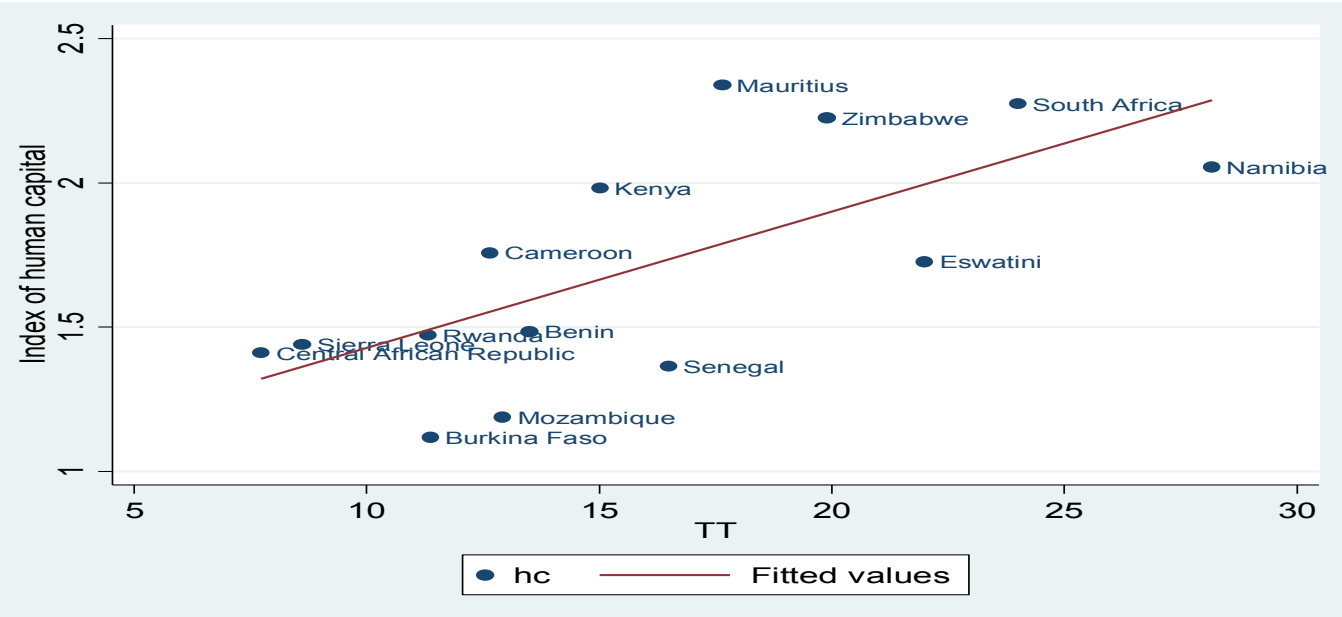

Figure 1: Scatterplot of total tax and index of human capital
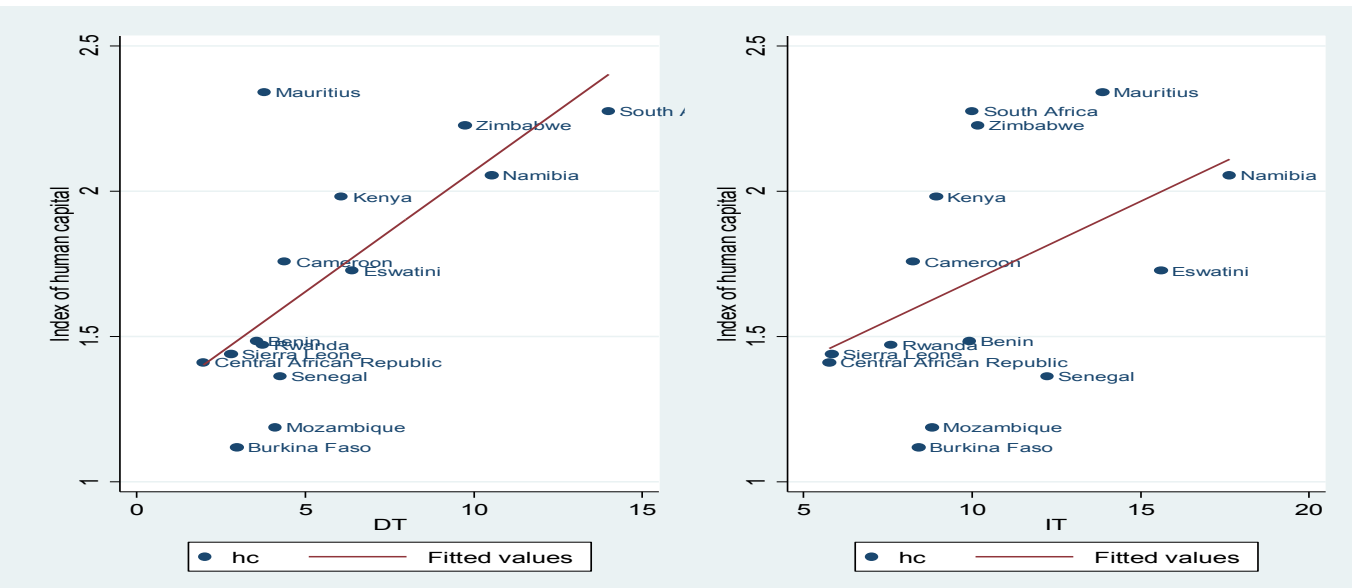

Figure 2: Scatterplots of types of tax and index of human capital 
Articles
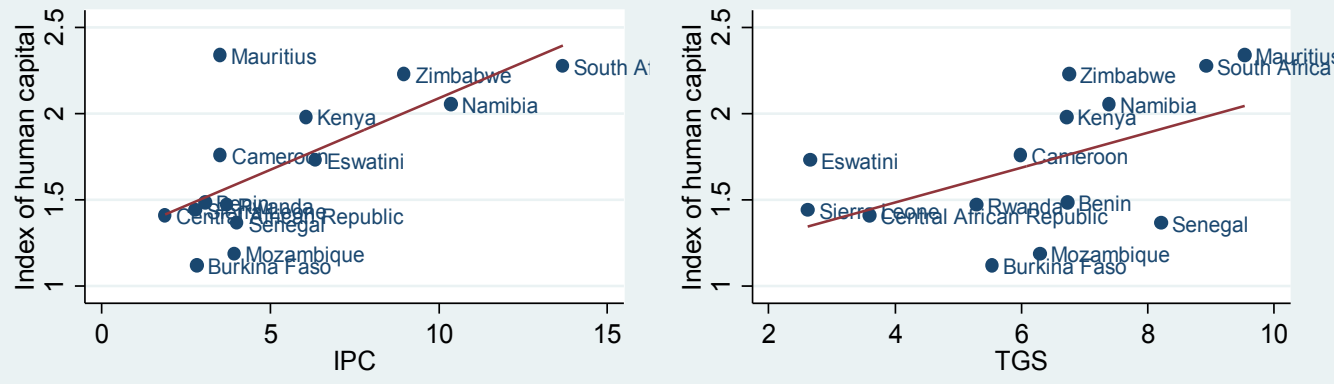

- hc Fitted values

- hc Fitted values

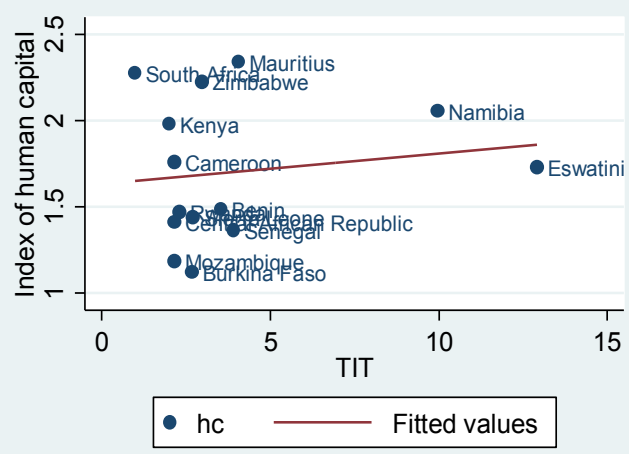

Figure 1: Scatterplots of tax components and index of human capital

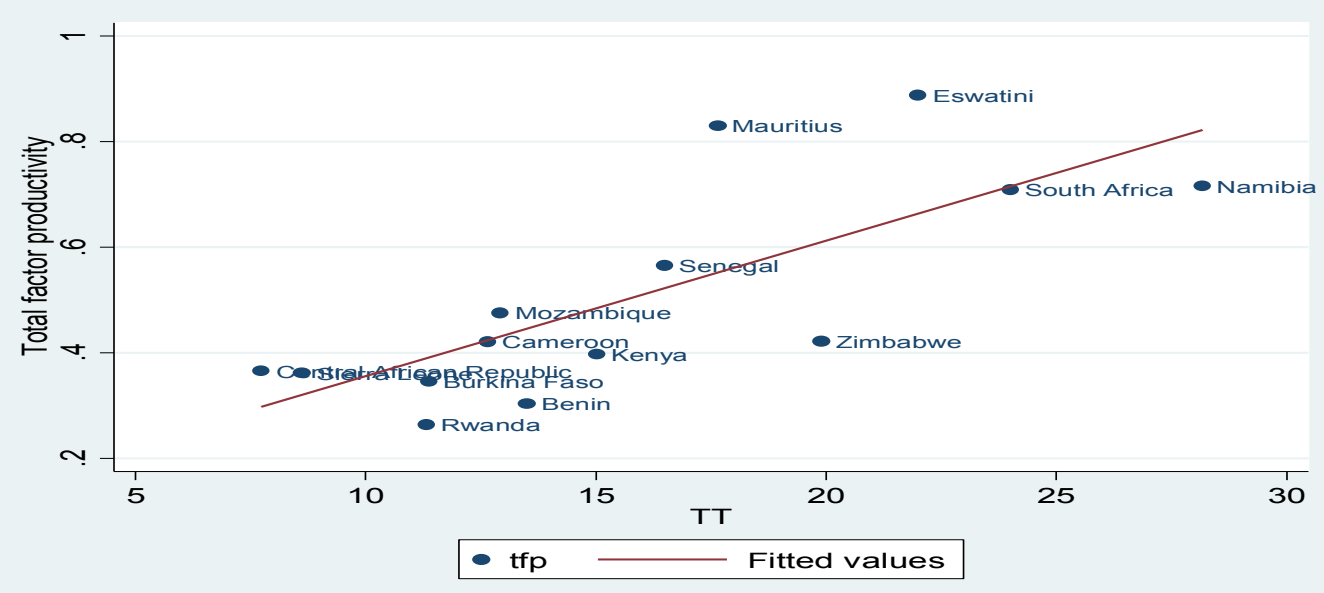

Figure 4: Scatterplot of total tax and total factor productivity 

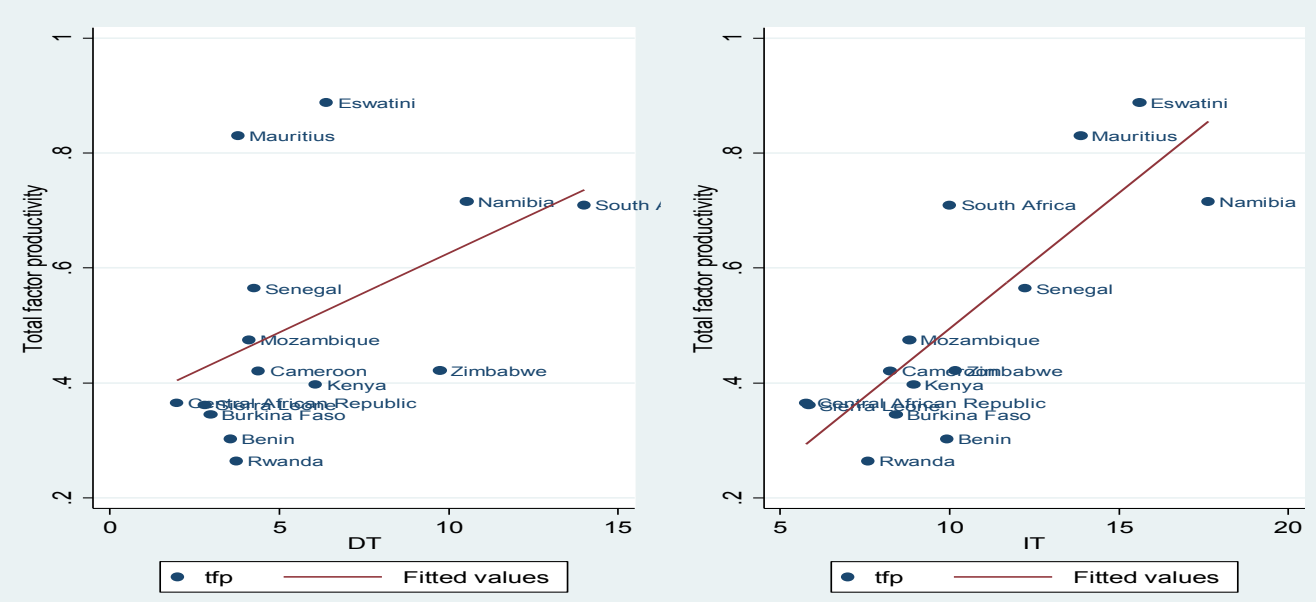

Figure 5: Scatterplots of types of tax and total factor productivity
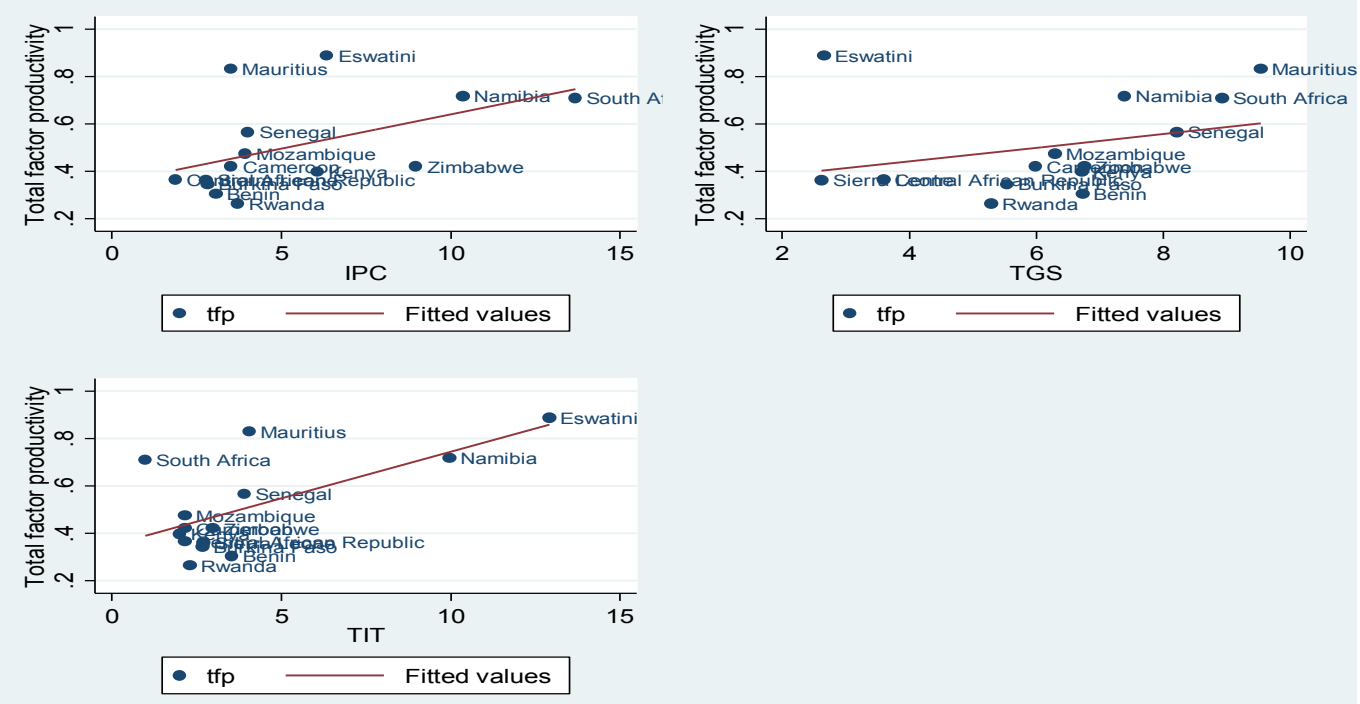

Figure 6: Scatterplots of tax components and total factor productivity

\subsection{The Impact Analysis}

Given the long-run relationship between taxes and human capital accumulation as well as other control variables, we estimated linear and nonlinear models as argued under the methodology. The Hausman test shows a non-rejection of the null hypothesis suggesting PMG as the efficient estimator for our analysis. Starting with linear models, Table 3 presents the results on the effect of taxes (aggregate and aggregated) on the index of human capital in the short-run and long-run periods. 


\section{Articles}

In the short-run analysis, the results show that all the measures of domestic resource mobilization are not statistically significant. In terms of directions and magnitudes, the coefficients are equally positive and negative but their magnitudes remain low. Economically, investment in human capital takes time before it can manifest which may account for the statistically insignificant of the coefficients. Accumulation of high skills and relevant knowledge takes a longer period before any economy can benefit from them. More so, the result shows that some taxes have the potential to amplify human capital accumulation in the SSA region.

However, all the coefficients are now statistically significant in the long-run. The result suggests that the utilization of total tax to finance an additional share of human capital is associated with an increase in overall human capital accumulation. Under the types of tax (direct and indirect), the result further suggests positive effects of domestic resource mobilization on the level of human capital. However, the effect of direct tax (0.11 percent) is significantly higher than indirect tax (0.02 percent). The result further shows that the parameter of direct tax is more statistically significant than indirect tax. On the components of taxes, taxes on income, profit and capital gains, and taxes on international trade positively and significantly influence the level of human capital while taxes on goods and services distort human capital accumulation. The extent to which taxes on income, profit, and capital gains, and taxes on international trade amplify the level of human capital accumulation is greater than the extent to which taxes on goods and services distort human capital accumulation. Thus, understanding the components of tax that can generate huge revenue to facilitate human capital accumulation is very important as this may prevent distortion to the level of human capital in an economy.

Exploring the total factor productivity measure of human capital (as presented in Table 4), the coefficient of total tax is relatively high, positive, and statistically significant in the short-run. Comparing this result with Table 3 , domestic resource mobilization can bring the desired change to the level of human capital accumulation in a short period. The direct tax remains positive and statistically insignificant but its magnitude is greater than the coefficient reported in Table 3. Under this alternative measure, the effect of indirect tax turns to be positive and higher on the level of human capital relative to previous findings. On the components of tax, only taxes on goods and services are distortionary while only taxes on international trade have a positive and significant effect on the level of human capital in the short-run.

In the long-run, all the measures of domestic resource mobilization are statistically significant but only direct tax and taxes on international trade negatively influence the level of human capital. All these findings point to the fact that domestic resource mobilization through taxation can provide funds for the development of human capital. Through this public financing option, the SSA countries can provide quality education, improve workers' skills, and acquisition of more relevant knowledge for the development of the region. These findings supported the argument of Oyinlola and Adedeji (2021) that tax mobilization can address the paucity of resources for human capital development. However, they contradict the findings of Bovenberga and Ewijk (1997) that argued that taxes (progressive) hampered human capital accumulation. 
Table 3: The Effect of Taxes on Human capital (Index of Human capital)

\begin{tabular}{|c|c|c|c|c|c|c|}
\hline VARIABLES & Model 1 & Model 2 & Model 3 & Model 4 & Model 5 & Model 6 \\
\hline \multicolumn{7}{|c|}{ Short-Run Coefficients } \\
\hline D.CRE & $\begin{array}{c}-0.000018 \\
(0.00006)\end{array}$ & $\begin{array}{c}-0.000058 \\
(0.00005)\end{array}$ & $\begin{array}{c}-0.000017 \\
(0.00007)\end{array}$ & $\begin{array}{l}-0.00005 \\
(0.00004)\end{array}$ & $\begin{array}{c}-0.000019 \\
(0.00004)\end{array}$ & $\begin{array}{l}-0.000019 \\
(0.00006)\end{array}$ \\
\hline D.FDI & $\begin{array}{c}0.00032^{* *} \\
(0.00015)\end{array}$ & $\begin{array}{c}0.00037^{*} \\
(0.0002)\end{array}$ & $\begin{array}{c}0.00033^{* *} \\
(0.00016)\end{array}$ & $\begin{array}{l}0.00037^{*} \\
(0.00022)\end{array}$ & $\begin{array}{c}0.00031^{* *} \\
(0.00015)\end{array}$ & $\begin{array}{c}0.00038^{* *} \\
(0.00016)\end{array}$ \\
\hline D.LGDPPC & $\begin{array}{c}0.00077 \\
(0.00065)\end{array}$ & $\begin{array}{c}0.00116^{\star * *} \\
(0.00044)\end{array}$ & $\begin{array}{l}0.00097^{*} \\
(0.00055)\end{array}$ & $\begin{array}{c}0.00132^{* * *} \\
(0.00040)\end{array}$ & $\begin{array}{c}0.00136^{* * *} \\
(0.00042)\end{array}$ & $\begin{array}{c}0.00141^{* * *} \\
(0.00054)\end{array}$ \\
\hline D.GOVT & $\begin{array}{l}-0.00006 \\
(0.00006)\end{array}$ & $\begin{array}{l}-0.00006 \\
(0.00005)\end{array}$ & $\begin{array}{l}-0.00007 \\
(0.00008)\end{array}$ & $\begin{array}{l}-0.0001 \\
(0.00007)\end{array}$ & $\begin{array}{l}-0.00007 \\
(0.00006)\end{array}$ & $\begin{array}{l}0.000005 \\
(0.00007)\end{array}$ \\
\hline D.TOP & $\begin{array}{l}-0.00002 \\
(0.00002)\end{array}$ & $\begin{array}{l}-0.00004 \\
(0.00004)\end{array}$ & $\begin{array}{c}-0.0002 \\
(0.00002)\end{array}$ & $\begin{array}{l}-0.00004 \\
(0.00004)\end{array}$ & $\begin{array}{l}-0.00003 \\
(0.00002)\end{array}$ & $\begin{array}{l}-0.00003 \\
(0.00002)\end{array}$ \\
\hline D.TT & $\begin{array}{l}-0.00008 \\
(0.00011)\end{array}$ & & & & & \\
\hline D.DT & & $\begin{array}{c}0.00039 \\
(0.00043)\end{array}$ & & & & \\
\hline D.IT & & & $\begin{array}{l}-0.00023 \\
(0.00017)\end{array}$ & & & \\
\hline D.IPC & & & & $\begin{array}{c}0.00047 \\
(0.00041)\end{array}$ & & \\
\hline D.TGS & & & & & $\begin{array}{c}-0.00011 \\
(0.00013)\end{array}$ & \\
\hline D.TIT & & & & & & $\begin{array}{l}-0.00007 \\
(0.00027)\end{array}$ \\
\hline ECM $(-1)$ & $\begin{array}{c}-0.392^{\star * *} \\
(0.0842)\end{array}$ & $\begin{array}{c}-0.382^{\star \star *} \\
(0.0843)\end{array}$ & $\begin{array}{c}-0.391^{* \star *} \\
(0.0792)\end{array}$ & $\begin{array}{c}-0.369 * \star \star \\
(0.0817)\end{array}$ & $\begin{array}{c}-0.423^{\star * *} \\
(0.0671)\end{array}$ & $\begin{array}{c}-0.398^{* * *} \\
(0.0925)\end{array}$ \\
\hline \multicolumn{7}{|c|}{ Long-Run Coefficients } \\
\hline CRE & $\begin{array}{l}0.00006^{*} \\
(0.00003)\end{array}$ & $\begin{array}{c}0.00004 \\
(0.00003)\end{array}$ & $\begin{array}{c}0.00006 \\
(0.00004)\end{array}$ & $\begin{array}{c}0.00002 \\
(0.00004)\end{array}$ & $\begin{array}{c}0.00008 \\
(0.00003)\end{array}$ & $\begin{array}{c}0.00013^{\star * *} \\
(0.00002)\end{array}$ \\
\hline FDI & $\begin{array}{l}-0.00003^{*} \\
(1.56 \mathrm{e}-05)\end{array}$ & $\begin{array}{c}-0.00004^{* * *} \\
(1.49 \mathrm{e}-05)\end{array}$ & $\begin{array}{c}-0.00002 \\
(1.92 e-05)\end{array}$ & $\begin{array}{c}-0.00004^{* * *} \\
(1.50 \mathrm{e}-05)\end{array}$ & $\begin{array}{l}-0.00005^{\star} \\
(2.67 e-05)\end{array}$ & $\begin{array}{c}-0.00007^{* * *} \\
(1.99 e-05)\end{array}$ \\
\hline LGDPPC & $\begin{array}{c}0.000706 \\
(0.000534)\end{array}$ & $\begin{array}{c}0.000551 \\
(0.000458)\end{array}$ & $\begin{array}{l}0.000983^{*} \\
(0.000558)\end{array}$ & $\begin{array}{c}0.000738 \\
(0.000485)\end{array}$ & $\begin{array}{c}0.000371 \\
(0.000467)\end{array}$ & $\begin{array}{l}-0.000300 \\
(0.000318)\end{array}$ \\
\hline GOVT & $\begin{array}{l}-0.00006 \\
(0.00005)\end{array}$ & $\begin{array}{c}-0.00018^{* * *} \\
(0.00005)\end{array}$ & $\begin{array}{l}-1.10 \mathrm{e}-05 \\
(0.00005)\end{array}$ & $\begin{array}{c}-0.000163^{* * *} \\
(0.00005)\end{array}$ & $\begin{array}{l}-5.82 \mathrm{e}-05 \\
(0.00006)\end{array}$ & $\begin{array}{c}-0.000109^{* *} \\
(0.00005)\end{array}$ \\
\hline TOP & $\begin{array}{c}-0.00002^{* * *} \\
(0.000006)\end{array}$ & $\begin{array}{c}-0.00004^{\star * *} \\
(0.000009)\end{array}$ & $\begin{array}{c}-0.00002^{\star *} \\
(0.000007)\end{array}$ & $\begin{array}{c}-0.000004^{* * *} \\
(0.000009)\end{array}$ & $\begin{array}{c}-0.00008 \\
(0.000009)\end{array}$ & $\begin{array}{l}0.00002^{* *} \\
(0.000007)\end{array}$ \\
\hline TT & $\begin{array}{c}0.00025^{* * *} \\
(0.00007)\end{array}$ & & & & & \\
\hline DT & & $\begin{array}{c}0.00114^{* * *} \\
(0.00021)\end{array}$ & & & & \\
\hline IT & & & $\begin{array}{c}0.00024^{* *} \\
(0.0001)\end{array}$ & & & \\
\hline IPC & & & & $\begin{array}{c}0.00102^{\star * *} \\
(0.00021)\end{array}$ & & \\
\hline TGS & & & & & $\begin{array}{c}-0.00015 \\
(0.0001)\end{array}$ & \\
\hline TIT & & & & & & $\begin{array}{c}0.00024^{* * *} \\
(0.00008)\end{array}$ \\
\hline CONSTANT & $\begin{array}{c}0.00086 \\
(0.00711)\end{array}$ & $\begin{array}{c}0.00159 \\
(0.00831)\end{array}$ & $\begin{array}{l}-0.00085 \\
(0.00708)\end{array}$ & $\begin{array}{l}-0.00053 \\
(0.00788)\end{array}$ & $\begin{array}{l}-0.0052 \\
(0.0075)\end{array}$ & $\begin{array}{l}-0.0029 \\
(0.0065)\end{array}$ \\
\hline
\end{tabular}


Articles

\begin{tabular}{lcccccc}
\hline \multicolumn{1}{c}{ VARIABLES } & Model 1 & Model 2 & Model 3 & Model 4 & Model 5 & Model 6 \\
\hline Hausman test & 0.00 & 0.00 & 0.00 & 0.01 & 0.00 & 0.00 \\
Log (likelihood) & 1909.2 & $(1.000)$ & $(1.000)$ & $(1.000)$ & $(1.000)$ & $(1.000)$ \\
No. of cross & 14 & 14 & 1910.8 & 1908.3 & 1904.2 & 1922.2 \\
sections & 364 & 364 & 14 & 14 & 14 & 14 \\
Observations & & 364 & 364 & 364 & 364 \\
\hline
\end{tabular}

Note: ***, **, and * denote 1, 5, and $10 \%$ levels of Significance, respectively while values in ( ) are standard errors. total tax (TT); direct taxes (DT); indirect tax (IT); taxes on income, profit, and capital gains (IPC), taxes on goods and services (TGS), and taxes on international trade (TIT). All are measured as a percentage of GDP. Credit to the private sector as a percentage of GDP (CRE); foreign direct investment as a percentage of GDP (FDI), GDP per capita (GDPPC); government final consumption as a percentage of GDP (GOVT), and trade openness (TOP).

Table 4: The Effect of Taxes on Human capital (Total Factor Productivity)

\begin{tabular}{|c|c|c|c|c|c|c|}
\hline VARIABLES & Model 1 & Model 2 & Model 3 & Model 4 & Model 5 & Model 6 \\
\hline \multicolumn{7}{|c|}{ Short-Run Coefficients } \\
\hline D.CRE & $\begin{array}{c}0.00108 \\
(0.00475)\end{array}$ & $\begin{array}{l}0.000589 \\
(0.00454)\end{array}$ & $\begin{array}{c}0.00127 \\
(0.00474)\end{array}$ & $\begin{array}{l}-0.00002 \\
(0.00472)\end{array}$ & $\begin{array}{c}-0.000361 \\
(0.00586)\end{array}$ & $\begin{array}{c}0.00161 \\
(0.00534)\end{array}$ \\
\hline D.FDI & $\begin{array}{l}0.00507^{*} \\
(0.00300)\end{array}$ & $\begin{array}{c}0.00436 \\
(0.00336)\end{array}$ & $\begin{array}{c}0.00432 \\
(0.00300)\end{array}$ & $\begin{array}{c}0.00471 \\
(0.00379)\end{array}$ & $\begin{array}{c}0.00412 \\
(0.00331)\end{array}$ & $\begin{array}{c}0.00266 \\
(0.00264)\end{array}$ \\
\hline D.LGDPPC & $\begin{array}{c}0.200^{\star * *} \\
(0.0656)\end{array}$ & $\begin{array}{l}0.191^{* * *} \\
(0.0636)\end{array}$ & $\begin{array}{c}0.206^{* * *} \\
(0.0655)\end{array}$ & $\begin{array}{c}0.202^{\star * *} \\
(0.0620)\end{array}$ & $\begin{array}{c}0.210^{* * *} \\
(0.0677)\end{array}$ & $\begin{array}{l}0.183^{* * *} \\
(0.0670)\end{array}$ \\
\hline D.GOVT & $\begin{array}{l}-0.00157 \\
(0.00341)\end{array}$ & $\begin{array}{c}0.00226 \\
(0.00261)\end{array}$ & $\begin{array}{l}-0.00192 \\
(0.00326)\end{array}$ & $\begin{array}{c}0.00230 \\
(0.00289)\end{array}$ & $\begin{array}{c}0.00325 \\
(0.00282)\end{array}$ & $\begin{array}{l}0.000255 \\
(0.00348)\end{array}$ \\
\hline D.TOP & $\begin{array}{c}-0.00010 \\
(0.00065)\end{array}$ & $\begin{array}{c}0.00008 \\
(0.00054)\end{array}$ & $\begin{array}{c}0.00030 \\
(0.00069)\end{array}$ & $\begin{array}{c}0.00010 \\
(0.00051)\end{array}$ & $\begin{array}{c}0.00022 \\
(0.00058)\end{array}$ & $\begin{array}{c}0.00003 \\
(0.00067)\end{array}$ \\
\hline D.TT & $\begin{array}{c}0.00806^{* *} \\
(0.0037)\end{array}$ & & & & & \\
\hline D.DT & & $\begin{array}{c}0.0202 \\
(0.0129)\end{array}$ & & & & \\
\hline D.IT & & & $\begin{array}{c}0.00708 \\
(0.00551)\end{array}$ & & & \\
\hline D.IPC & & & & $\begin{array}{c}0.0170 \\
(0.0106)\end{array}$ & & \\
\hline D.TGS & & & & & $\begin{array}{l}-0.00484 \\
(0.00702)\end{array}$ & \\
\hline D.TIT & & & & & & $\begin{array}{c}0.0269 * * * \\
(0.00711)\end{array}$ \\
\hline ECM $(-1)$ & $\begin{array}{c}-0.239 * * * \\
(0.0627)\end{array}$ & $\begin{array}{c}-0.264^{* * *} \\
(0.0754) \\
\end{array}$ & $\begin{array}{c}-0.238^{* * *} \\
(0.0615)\end{array}$ & $\begin{array}{c}-0.261^{* * *} \\
(0.0737)\end{array}$ & $\begin{array}{c}-0.143^{\star * *} \\
(0.0441) \\
\end{array}$ & $\begin{array}{c}-0.165^{\star \star *} \\
(0.0585)\end{array}$ \\
\hline \multicolumn{7}{|c|}{ Long-Run Coefficients } \\
\hline CRE & $\begin{array}{c}0.00158^{*} \\
(0.000925)\end{array}$ & $\begin{array}{l}0.00186^{\star} \\
(0.00106)\end{array}$ & $\begin{array}{c}0.00166 \\
(0.00101)\end{array}$ & $\begin{array}{c}0.00161 \\
(0.000991)\end{array}$ & $\begin{array}{c}0.00220 \\
(0.00220)\end{array}$ & $\begin{array}{c}0.00288^{* *} \\
(0.00117)\end{array}$ \\
\hline FDI & $\begin{array}{c}-0.0102^{* *} \\
(0.00439)\end{array}$ & $\begin{array}{c}-0.0120^{* * *} \\
(0.00263)\end{array}$ & $\begin{array}{c}-0.00848^{*} \\
(0.00449)\end{array}$ & $\begin{array}{c}-0.0104^{\star * *} \\
(0.00260)\end{array}$ & $\begin{array}{l}-0.00907 \\
(0.00619)\end{array}$ & $\begin{array}{c}-0.00920^{* *} \\
(0.00420)\end{array}$ \\
\hline LGDPPC & $\begin{array}{c}-0.100^{\star * *} \\
(0.0256)\end{array}$ & $\begin{array}{c}-0.141^{* * *} \\
(0.0291)\end{array}$ & $\begin{array}{c}-0.101^{\star * *} \\
(0.0261)\end{array}$ & $\begin{array}{c}-0.173^{\star * *} \\
(0.0308)\end{array}$ & $\begin{array}{c}-0.340^{* * *} \\
(0.0815)\end{array}$ & $\begin{array}{c}-0.171^{\star * *} \\
(0.0320)\end{array}$ \\
\hline GOVT & $\begin{array}{l}-0.00425 \\
(0.00465)\end{array}$ & $\begin{array}{c}-0.00886^{\star} \\
(0.00479)\end{array}$ & $\begin{array}{l}-0.00234 \\
(0.00541)\end{array}$ & $\begin{array}{c}-0.00806^{\star} \\
(0.00463)\end{array}$ & $\begin{array}{c}-0.0358^{* * *} \\
(0.00610)\end{array}$ & $\begin{array}{c}-0.0181^{* * *} \\
(0.00546)\end{array}$ \\
\hline
\end{tabular}




\begin{tabular}{|c|c|c|c|c|c|c|}
\hline VARIABLES & Model 1 & Model 2 & Model 3 & Model 4 & Model 5 & Model 6 \\
\hline TOP & $\begin{array}{c}0.00194^{* * *} \\
(0.000414)\end{array}$ & $\begin{array}{c}0.00232^{* * *} \\
(0.000559)\end{array}$ & $\begin{array}{c}0.00198^{* * *} \\
(0.000444)\end{array}$ & $\begin{array}{l}0.00181^{* * *} \\
(0.000532)\end{array}$ & $\begin{array}{l}0.00301^{*} \\
(0.00174)\end{array}$ & $\begin{array}{c}0.00155^{\star * *} \\
(0.000577)\end{array}$ \\
\hline TT & $\begin{array}{c}0.0158^{* * *} \\
(0.00432)\end{array}$ & & & & & \\
\hline DT & & $\begin{array}{c}-0.0315^{\star * *} \\
(0.0101)\end{array}$ & & & & \\
\hline IT & & & $\begin{array}{c}0.0163^{\star * * *} \\
(0.00508)\end{array}$ & & & \\
\hline IPC & & & & $\begin{array}{c}-0.0407^{* * *} \\
(0.00979)\end{array}$ & & \\
\hline TGS & & & & & $\begin{array}{c}0.0545^{\star \star *} \\
(0.0170)\end{array}$ & \\
\hline TIT & & & & & & $\begin{array}{c}-0.104^{* * *} \\
(0.0236)\end{array}$ \\
\hline CONSTANT & $\begin{array}{l}0.0284 \\
(0.271)\end{array}$ & $\begin{array}{l}-0.300 \\
(0.210)\end{array}$ & $\begin{array}{c}-0.00860 \\
(0.246)\end{array}$ & $\begin{array}{l}-0.353 \\
(0.230)\end{array}$ & $\begin{array}{c}0.121 \\
(0.250)\end{array}$ & $\begin{array}{c}0.134 \\
(0.190)\end{array}$ \\
\hline Hausman test & $0.11(1.000)$ & $0.06(1.000)$ & $0.13(1.000)$ & $0.14(1.000)$ & $0.12(1.000)$ & $0.23(0.9998)$ \\
\hline Log (likelihood) & 692.3 & 701.0 & 688.7 & 696.9 & 680.3 & 702.0 \\
\hline $\begin{array}{l}\text { No. of cross } \\
\text { sections }\end{array}$ & 14 & 14 & 14 & 14 & 14 & 14 \\
\hline Observations & 378 & 378 & 378 & 378 & 378 & 378 \\
\hline
\end{tabular}

Note: ***, **, and * denote $1 \%, 5 \%$, and $10 \%$ levels of Significance, respectively while values in ( ) are standard errors. total tax (TT); direct taxes (DT); indirect tax (IT); taxes on income, profit, and capital gains (IPC), taxes on goods and services (TGS), and taxes on international trade (TIT). All are measured as a percentage of GDP. Credit to the private sector as a percentage of GDP (CRE); foreign direct investment as a percentage of GDP (FDI), GDP per capita (GDPPC); government final consumption as a percentage of GDP (GOVT), and trade openness (TOP).

Shifting discussions to the control variables, the results in Table 3 show that the coefficients of credit to the private sector are negative and statistically insignificant across the models in the short run. However, the results change in the long-run as the coefficients turn to be positive but only statistically significant in models 1 and 2 . On the other hand, the short-run estimates of credit to the private sector are largely positive across all the measures of domestic resource mobilization in Table 4. In the long-run, all the estimates change to positive signs but are only statistically significant in models 1,2 , and 6 . These results from the two measures of human capital suggest that the financial sector has a role to play in enhancing the level of human capital accumulation. Though its impact is still very small judged by the magnitudes. The sector can improve the skills and knowledge of workers by designing effective and efficient credit facilities for such development indicators. These findings supported the argument of some studies such as Oyinlola and Adedeji (2020) and Bencivenga and Smith (1991).

Interestingly, foreign direct investment exerts a positive impact on human capital measures in the short-run period as presented in Tables 3 and 4. However, all the coefficients are statistically significant under the index of human capital but only significant in model 1 under total factor productivity. In the long-run, the estimates are all negative and statistically significant. These results show that the effect of foreign direct investment into the region 


\section{Articles}

has a temporary effect on human capital accumulation. This reaffirms the dominant argument in the literature that most foreign investments go to an extractive industry where there is little human capacity development and knowledge spillover (Chen, et al., 2017; Guo and Clougherty, 2015; Mohan, 2013). Thus, the nature of foreign direct investment in the SSA region does have the potential to amplify the level of human capital development in the long-run.

On the GDP per capita which captures the level of individual income in the economy, all its short-run coefficients are positive and statistically significant under both measures. However, the positive effect is significantly greater under total factor productivity compared to the index of human capital. The results indicate that the level of individual income determines the level to which they can acquire more education, skills, and knowledge. Thus, the SSA countries need to ensure improvement in the income level of the citizens as the government alone cannot accumulate or develop the required level of human capital in the region. The long-run results show that the estimates are largely positive but trivial in Table 3 compared to the negative impact across the models in Table 4. The implication of this is that people tend to invest more in education, skills, and knowledge acquisition at an early period while the level of investment in human capital reduces in the later period. On government final consumption, its short-run and long-run estimates suggest that it dampens the level of human capital in Table 3. On the other hand, the short-run estimates are largely positive while its long-run estimates are negative across the model in Table 4. We can conclude that most public sector consumptions do not benefit human capacity building in most SSA countries.

Accounting for the role of external trade, there are mixed results under the two measures. The short-run and long-run estimates show that trade openness has a drag effect on human capital accumulation under the first measure. However, the results under total factor productivity suggest that trade openness facilitates the accumulation of human capital in the short-run and longrun periods. We can infer from these results that the region needs to intensify effort towards deriving human capital benefits that come with trade such as the transfer of skills and knowledge. Additionally, the speed of adjustment parameters (ECM) suggests longrun convergence across the models but the period it will take these systems to converge to their long-run equilibrium in the presence of any shock differs across the measures of domestic resource mobilization under the two measures of human capital accumulation. 
Table 5: The Nonlinear Effect of Taxes on Human capital (Index of Human Capital)

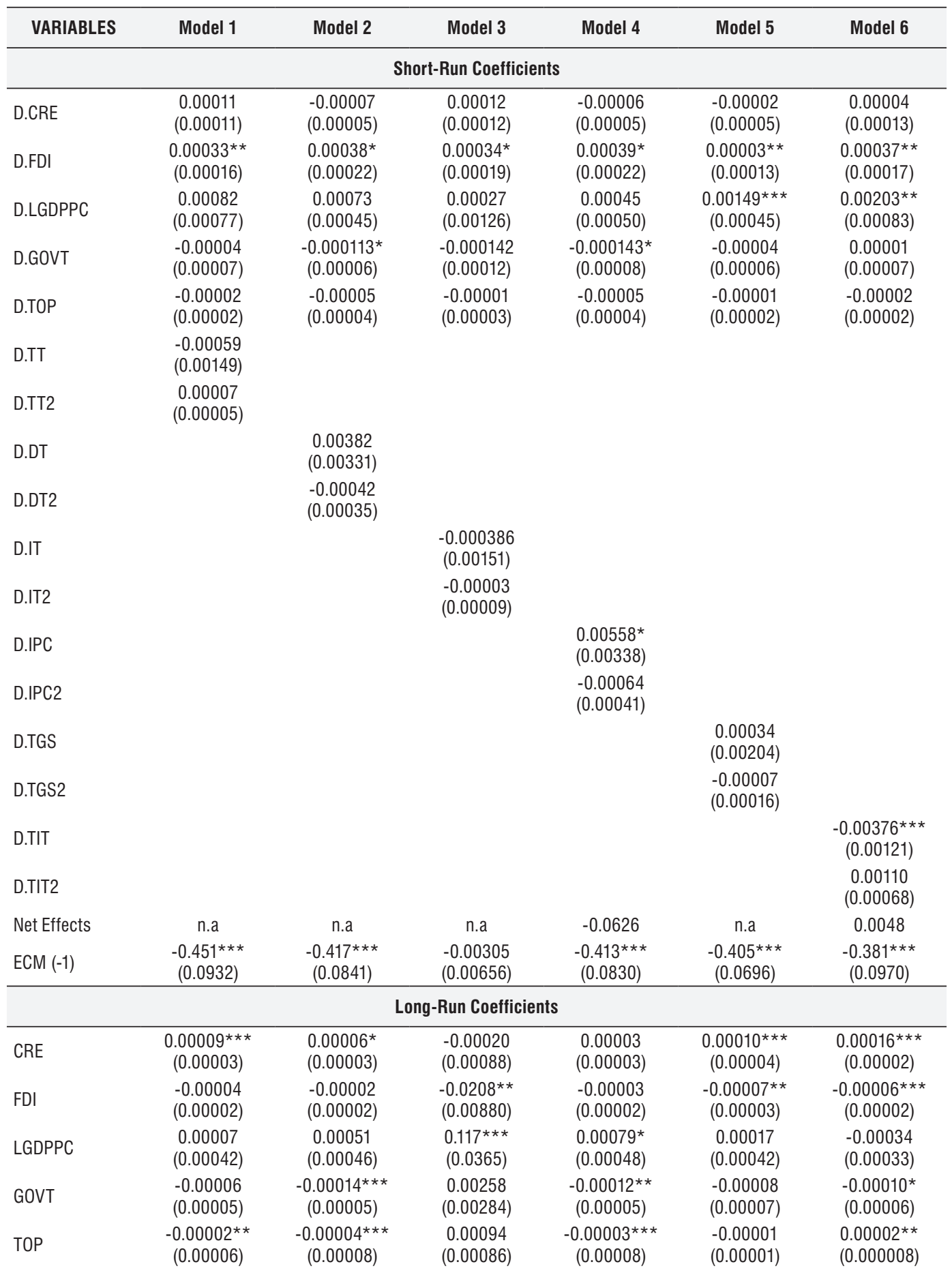


Articles

\begin{tabular}{|c|c|c|c|c|c|c|}
\hline VARIABLES & Model 1 & Model 2 & Model 3 & Model 4 & Model 5 & Model 6 \\
\hline TT & $\begin{array}{c}0.00076^{\star \star *} \\
(0.00013)\end{array}$ & & & & & \\
\hline TT2 & $\begin{array}{c}-0.00003^{* * *} \\
(0.000006)\end{array}$ & & & & & \\
\hline DT & & $\begin{array}{c}0.00142^{* * *} \\
(0.00027)\end{array}$ & & & & \\
\hline DT2 & & $\begin{array}{c}-0.00008^{* *} \\
(0.00003)\end{array}$ & & & & \\
\hline IT & & & $\begin{array}{c}0.0284 \\
(0.0207)\end{array}$ & & & \\
\hline IT2 & & & $\begin{array}{l}-0.00083 \\
(0.00069)\end{array}$ & & & \\
\hline IPC & & & & $\begin{array}{c}0.00125^{\star * *} \\
(0.00026)\end{array}$ & & \\
\hline IPC2 & & & & $\begin{array}{c}-0.00007^{* *} \\
(0.00003)\end{array}$ & & \\
\hline TGS & & & & & $\begin{array}{c}0.00034 \\
(0.00027)\end{array}$ & \\
\hline TGS2 & & & & & $\begin{array}{c}-0.00003^{*} \\
(0.00002)\end{array}$ & \\
\hline TIT & & & & & & $\begin{array}{c}0.00059 * * \\
(0.00028)\end{array}$ \\
\hline TIT2 & & & & & & $\begin{array}{l}-0.00005 \\
(0.00003)\end{array}$ \\
\hline CONSTANT & $\begin{array}{l}-0.00537 \\
(0.00794)\end{array}$ & $\begin{array}{c}0.00095 \\
(0.00841)\end{array}$ & $\begin{array}{l}0.00044 \\
(0.0187)\end{array}$ & $\begin{array}{l}-0.00056 \\
(0.00831)\end{array}$ & $\begin{array}{l}-0.00590 \\
(0.00645)\end{array}$ & $\begin{array}{c}0.00168 \\
(0.00640)\end{array}$ \\
\hline Net Effects & -0.0002 & 0.0005 & n.a & 0.0005 & -0.00003 & 0.0002 \\
\hline Hausman test & $0.00(1.000)$ & $0.01(1.000)$ & $0.00(1.000)$ & $0.01(1.000)$ & $0.00(1.000)$ & $0.00(1.000)$ \\
\hline Log(likelihood) & 1929.1 & 1919.7 & 1898.4 & 1914.0 & 1917.7 & 1934.2 \\
\hline $\begin{array}{l}\text { No. of cross } \\
\text { sections }\end{array}$ & 14 & 14 & 14 & 14 & 14 & 14 \\
\hline Observations & 364 & 364 & 364 & 364 & 364 & 364 \\
\hline
\end{tabular}

Note: ***, **, and * denote 1, 5, and 10\% levels of Significance, respectively while values in ( ) are standard errors. total tax (TT); direct taxes (DT); indirect tax (IT); taxes on income, profit, and capital gains (IPC), taxes on goods and services (TGS), and taxes on international trade (TIT). All are measured as a percentage of GDP. Credit to the private sector as a percentage of GDP (CRE); foreign direct investment as a percentage of GDP

(FDI), GDP per capita (GDPPC); government final consumption as a percentage of GDP (GOVT), and trade openness (TOP). n.a: not applicable since leastwise one estimated parameter must be statistically significant for the computation of net effects. Thus, the nonlinear models that do not fulfill this criterion are exempted.

We now focus discussions on the nonlinear results presented in Tables 5 and 6. Starting with key variables of interest (i.e., measures of domestic resource mobilization), the shortrun coefficients are not statistically significant but are negative and positive under the index of human capital and total factor productivity, respectively. The effect of total tax is positive under the two measures of human capital but

only statistically significant in Table 5 . This suggests that the parameter is somewhat sensitive to the measures of human capital. On direct tax, the short-run coefficients are mixed but not statistically significant under the two measures. However, its long-run estimates indicate a positive and significant impact of a direct tax on two measures of human capital accumulation. Also, the short- 


\section{Articles}

run and long-run estimates are negative and positive, respectively, but are not statistically significant under the index of human capital. However, the short-run and long-run estimates indicate a positive impact of indirect tax under total factor productivity but only statistically significant in the long-run period. On tax components, the short-run and long-run estimates of taxes on income, profit, and capital gains are both positive and statistically significant under the index of human capital while mixed results are observed in the shortrun and long-run periods under total factor productivity. Also, the coefficients of taxes on goods and services are positive in results reported in Tables 5 and 6 . However, there are mixed results as shown by both short-run and long-run coefficients in Tables 5 and 6.

Testing for the 'human capital laffer curve' (HCLC), the results indicate that when considering total tax, there is no presence of HCLC in the short-run but in the long-run in Table 5 while there is no presence of HCLC in the short-run and long-run in Table 6. The result under the first measure (index of human capital) implies that there is HCLC in long-run period. This means that there is an optimal level of total tax that can maximise the level of human capital accumulation. The excess tax rate may crowd out other factors that facilitate human capital accumulation. We further interrogate the presence of HCLC under types of tax. There is no presence of HCLC in the short-run under both measures of human capital. However, only direct taxes fulfilled the conditions of HCLC while there is no presence of HCLC as reported in Table 5.

A similar result is observed in Table 6 . Thus, there is an optimal level of direct tax that can facilitate human capital accumulation. In essence, the low tax may generate low revenue for the government to finance human
Domestic Resource Mobilization and Human Capital

Development in Sub-Saharan Africa

capital development while excessive tax may be detrimental to the accumulation of human capital. This is expected as taxing individual income or company's profit excessively may significantly discourage people or companies from investing in human capital accumulation. Among the components of tax, there is no presence of HCLC in the short-run but in the long-run in Tables 5 and 6. Specifically, taxes on income, profit, and capital gains, and taxes on goods and services have a nonlinear effect on human capital accumulation under the first measure of human capital in the longrun. On the other hand, only taxes on goods and services have the presence of HCLC.

Considering the overall effects of taxes in human capital development, net effects are computed for both short-run and longrun periods in Tables 5 and 6 . This is in line with coeval literature on quadratic regressions (Asongu and Odhiambo, 2020a \& 2020b; Boateng et al., 2018). For instance, in model 4 of Table 5, the short-run net effect for enhancing taxes on income, profit, and capital gains on human capital is -0.0626 . This is computed as: $[2 \times(0.0056 \times-0.0064)+$ $(0.0056)]=0.0626$. From our calculation, the average value is 5.329 (see summary table), the unconditional effect of IPC is 0.0056 , and the conditional effect of IPC is -0.0064 . This approach is explored for calculations of other net effects in Tables 5 and 6 . From table 5, the short-run net effects for enhancing taxes on income, profit, and capital gains are negative while positive for taxes on international trade. In the long-run, the net effects are positive for direct tax, tax on income, profit and gains, and tax on international trade whereas negative net effects are arising from total tax and taxes on goods and services. In Table 6 , the short-run net effect of enhancing taxes on international trade does not amplify this measure of human 


\section{Articles}

capital development. In the long-run, there are positive net effects from facilitating indirect tax and taxes on goods and services on human capital development. However, an increase in total tax, direct tax, and taxes on income, profit, and gains has negative net effects on human capital development. Therefore, we can infer from the results of the net effects that not all taxes are distortionary in improving the level of human capital development in the SSA region. Finally, the speed of adjustment parameters (ECM) shows convergence of our variable in the long-run across the models. However, the period required for SSA economy to converge to their long-run equilibrium (during any shock) at different levels of domestic resource mobilization (under the two measures of human capital accumulation) varies.

Table 6: The Nonlinear Effect of Taxes on Human capital (Total Factor Productivity)

\begin{tabular}{|c|c|c|c|c|c|c|}
\hline VARIABLES & Model 1 & Model 2 & Model 3 & Model 4 & Model 5 & Model 6 \\
\hline \multicolumn{7}{|c|}{ Short-Run Coefficients } \\
\hline D.CRE & $\begin{array}{l}0.00351 \\
(0.00495)\end{array}$ & $\begin{array}{l}0.00185 \\
(0.00436)\end{array}$ & $\begin{array}{l}0.00259 \\
(0.00530)\end{array}$ & $\begin{array}{l}0.000419 \\
(0.00454)\end{array}$ & $\begin{array}{l}0.00243 \\
(0.00587)\end{array}$ & $\begin{array}{l}0.00224 \\
(0.00517)\end{array}$ \\
\hline D.FDI & $\begin{array}{l}0.00582^{* *} \\
(0.00283)\end{array}$ & $\begin{array}{l}0.00398 \\
(0.00322)\end{array}$ & $\begin{array}{l}0.00328 \\
(0.00302)\end{array}$ & $\begin{array}{l}0.00568 \\
(0.00461)\end{array}$ & $\begin{array}{l}0.00580 \\
(0.00419)\end{array}$ & $\begin{array}{l}0.00270 \\
(0.00247)\end{array}$ \\
\hline D.LGDPPC & $\begin{array}{l}0.202^{* * *} \\
(0.0654)\end{array}$ & $\begin{array}{l}0.190 * \star * \\
(0.0653)\end{array}$ & $\begin{array}{l}0.205^{\star \star \star} \\
(0.0637)\end{array}$ & $\begin{array}{l}0.199 * \star * \\
(0.0598)\end{array}$ & $\begin{array}{l}0.198 * * * \\
(0.0713)\end{array}$ & $\begin{array}{l}0.182^{\star \star *} \\
(0.0678)\end{array}$ \\
\hline D.GOVT & $\begin{array}{l}0.000212 \\
(0.00298)\end{array}$ & $\begin{array}{l}0.000218 \\
(0.00237)\end{array}$ & $\begin{array}{l}0.000940 \\
(0.00292)\end{array}$ & $\begin{array}{l}0.00120 \\
(0.00297)\end{array}$ & $\begin{array}{l}0.00185 \\
(0.00256)\end{array}$ & $\begin{array}{l}-0.00152 \\
(0.00351)\end{array}$ \\
\hline D.TOP & $\begin{array}{l}1.77 e-05 \\
(0.000668)\end{array}$ & $\begin{array}{l}0.000122 \\
(0.000605)\end{array}$ & $\begin{array}{l}0.000158 \\
(0.000558)\end{array}$ & $\begin{array}{l}6.03 e-05 \\
(0.000582)\end{array}$ & $\begin{array}{l}9.11 \mathrm{e}-05 \\
(0.000629)\end{array}$ & $\begin{array}{l}-0.000136 \\
(0.000651)\end{array}$ \\
\hline D.TT & $\begin{array}{l}0.0651 \\
(0.0490)\end{array}$ & & & & & \\
\hline D.TT2 & $\begin{array}{l}-0.00217 \\
(0.00173)\end{array}$ & & & & & \\
\hline D.DT & & $\begin{array}{l}-0.00205 \\
(0.0516)\end{array}$ & & & & \\
\hline D.DT2 & & $\begin{array}{l}0.000446 \\
(0.00617)\end{array}$ & & & & \\
\hline D.IT & & & $\begin{array}{l}0.0138 \\
(0.0559)\end{array}$ & & & \\
\hline D.IT2 & & & $\begin{array}{l}-0.00168 \\
(0.00293)\end{array}$ & & & \\
\hline D.IPC & & & & $\begin{array}{l}0.0551 \\
(0.0574)\end{array}$ & & \\
\hline D.IPC2 & & & & $\begin{array}{l}-0.00778 \\
(0.00944)\end{array}$ & & \\
\hline D.TGS & & & & & $\begin{array}{l}0.0106 \\
(0.0336)\end{array}$ & \\
\hline D.TGS2 & & & & & $\begin{array}{l}-0.00346 \\
(0.00478)\end{array}$ & \\
\hline D.TIT & & & & & & $\begin{array}{l}0.129 * \\
(0.0696)\end{array}$ \\
\hline D.TIT2 & & & & & & $\begin{array}{l}-0.0201 \\
(0.0183)\end{array}$ \\
\hline Net Effects & n.a & n.a & n.a & n.a & n.a & -0.0271 \\
\hline $\operatorname{ECM}(-1)$ & $\begin{array}{l}-0.168^{\star * *} \\
(0.0595)\end{array}$ & $\begin{array}{l}-0.266^{\star * *} \\
(0.0750)\end{array}$ & $\begin{array}{l}-0.174^{\star \star *} \\
(0.0442)\end{array}$ & $\begin{array}{l}-0.263^{* * *} \\
(0.0754)\end{array}$ & $\begin{array}{l}-0.188^{* * *} \\
(0.0473)\end{array}$ & $\begin{array}{l}-0.144^{\star * *} \\
(0.0477)\end{array}$ \\
\hline
\end{tabular}




\begin{tabular}{|c|c|c|c|c|c|c|}
\hline VARIABLES & Model 1 & Model 2 & Model 3 & Model 4 & Model 5 & Model 6 \\
\hline \multicolumn{7}{|c|}{ Long-Run Coefficients } \\
\hline CRE & $\begin{array}{l}-0.0119 * * * \\
(0.00349)\end{array}$ & $\begin{array}{l}0.00134 \\
(0.000943)\end{array}$ & $\begin{array}{l}-0.0217^{\star * *} \\
(0.00447)\end{array}$ & $\begin{array}{l}0.00152 \\
(0.000964)\end{array}$ & $\begin{array}{l}-0.0149 * * * \\
(0.00433)\end{array}$ & $\begin{array}{l}0.000816 \\
(0.00158)\end{array}$ \\
\hline FDI & $\begin{array}{l}-0.0127^{\star * *} \\
(0.00279)\end{array}$ & $\begin{array}{l}-0.0125^{\star * *} \\
(0.00249)\end{array}$ & $\begin{array}{l}-0.00501 \\
(0.00328)\end{array}$ & $\begin{array}{l}-0.0101^{* * *} \\
(0.00232)\end{array}$ & $\begin{array}{l}-0.00803^{* *} \\
(0.00322)\end{array}$ & $\begin{array}{l}-0.0127^{* * *} \\
(0.00414)\end{array}$ \\
\hline LGDPPC & $\begin{array}{l}-0.194^{\star *} \\
(0.0847)\end{array}$ & $\begin{array}{l}-0.149 * * * \\
(0.0252)\end{array}$ & $\begin{array}{l}-0.239 * * * \\
(0.0808)\end{array}$ & $\begin{array}{l}-0.162^{* * *} \\
(0.0294)\end{array}$ & $\begin{array}{l}-0.112 \\
(0.0783)\end{array}$ & $\begin{array}{l}-0.201^{\star * *} \\
(0.0402)\end{array}$ \\
\hline GOVT & $\begin{array}{l}0.00506 \\
(0.00569)\end{array}$ & $\begin{array}{l}-0.00711 \\
(0.00436)\end{array}$ & $\begin{array}{l}-0.0179 * * * \\
(0.00554)\end{array}$ & $\begin{array}{l}-0.00499 \\
(0.00437)\end{array}$ & $\begin{array}{l}-0.0105^{\star} \\
(0.00577)\end{array}$ & $\begin{array}{l}-0.0102 \\
(0.00673)\end{array}$ \\
\hline TOP & $\begin{array}{l}0.00317^{\star \star \star} \\
(0.00122)\end{array}$ & $\begin{array}{l}0.00197^{\star \star \star} \\
(0.000457)\end{array}$ & $\begin{array}{l}0.00144 \\
(0.00142)\end{array}$ & $\begin{array}{l}0.00167^{* * *} \\
(0.000500)\end{array}$ & $\begin{array}{l}0.00338^{* *} \\
(0.00141)\end{array}$ & $\begin{array}{l}0.00143^{* *} \\
(0.000637)\end{array}$ \\
\hline TT & $\begin{array}{l}-0.0553^{*} \\
(0.0323)\end{array}$ & & & & & \\
\hline TT2 & $\begin{array}{l}0.00125 \\
(0.000916)\end{array}$ & & & & & \\
\hline DT & & $\begin{array}{l}0.0558^{\star *} \\
(0.0229)\end{array}$ & & & & \\
\hline DT2 & & $\begin{array}{l}-0.00564^{\star \star *} \\
(0.00145)\end{array}$ & & & & \\
\hline IT & & & $\begin{array}{l}0.0763^{*} \\
(0.0391)\end{array}$ & & & \\
\hline IT2 & & & $\begin{array}{l}-0.000946 \\
(0.00150)\end{array}$ & & & \\
\hline IPC & & & & $\begin{array}{l}-0.00908 \\
(0.0189)\end{array}$ & & \\
\hline IPC2 & & & & $\begin{array}{l}-0.00237^{\star *} \\
(0.00119)\end{array}$ & & \\
\hline TGS & & & & & $\begin{array}{l}0.150 * * * \\
(0.0547)\end{array}$ & \\
\hline TGS2 & & & & & $\begin{array}{l}-0.00859 * * \\
(0.00412)\end{array}$ & \\
\hline TIT & & & & & & $\begin{array}{l}-0.00201 \\
(0.0863)\end{array}$ \\
\hline TIT2 & & & & & & $\begin{array}{l}-0.0193 \\
(0.0143)\end{array}$ \\
\hline CONSTANT & $\begin{array}{l}-0.580^{* *} \\
(0.281)\end{array}$ & $\begin{array}{l}-0.282 \\
(0.202)\end{array}$ & $\begin{array}{l}-0.307 \\
(0.199)\end{array}$ & $\begin{array}{l}-0.370^{*} \\
(0.219)\end{array}$ & $\begin{array}{l}-0.324^{*} \\
(0.170)\end{array}$ & $\begin{array}{l}-0.00749 \\
(0.200)\end{array}$ \\
\hline Net Effects & -0.0158 & -0.0072 & 0.0570 & -0.0343 & 0.4400 & n.a \\
\hline Hausman test & $0.01(1.000)$ & $0.06(1.000)$ & $0.01(1.000)$ & $0.06(1.000)$ & $0.01(1.000)$ & $0.25(0.999)$ \\
\hline Log(likelihood) & 713.3 & 722.0 & 717.6 & 712.4 & 704.3 & 721.8 \\
\hline $\begin{array}{l}\text { No. of cross } \\
\text { sections }\end{array}$ & 14 & 14 & 14 & 14 & 14 & 14 \\
\hline Observations & 378 & 378 & 378 & 378 & 378 & 378 \\
\hline
\end{tabular}

Note: ${ }^{* * *},{ }^{* *}$, and ${ }^{*}$ denote 1,5 , and $10 \%$ levels of Significance, respectively while values in ( ) are standard errors. total tax (TT); direct taxes (DT); indirect tax (IT); taxes on income, profit, and capital gains (IPC), taxes on goods and services (TGS), and taxes on international trade (TIT). All are measured as a percentage of GDP. Credit to the private sector as a percentage of GDP (CRE); foreign direct investment as a percentage of GDP (FDI), GDP per capita (GDPPC); government final consumption as a percentage of GDP (GOVT), and trade openness (TOP). n.a: not applicable since leastwise one estimated parameter must be statistically significant for the computation of net effects. Thus, the nonlinear models that do not fulfill this criterion are exempted. 


\section{Articles}

\section{Conclusion and Policy Implications}

Exploring the PARDL modelling technique with annual time series data between 1990 and 2017, the study investigated the role of domestic resource mobilization on human capital using 14 SSA countries. This study deviated from extant studies by analysing investment in human capital accumulation through domestic resource mobilization rather than economic growth. Two measures of human capital were considered: (i) index of human capital and (ii) total factor productivity. The result of scatterplots revealed a positive relationship between different measures of domestic resource mobilization and human capital. However, the analysis further showed a slightly positive relationship between taxes on international trade and the index of human capital, and total factor productivity is slightly and positively correlated with taxes on goods and services.

The study further considered both linear and nonlinear effects of tax on human capital accumulation. The finding from the linear models showed that all measures of domestic resource mobilization positively influence the level of human capital accumulation but are not statistically significant (index of human capital) in the short-run period. Additionally, the results indicated a positive and significant influence of all measures of domestic resource mobilisation on human capital accumulation in the long-run period. When total factor productivity measure of human capital was considered, the short-run impact of domestic resource mobilization measures is similar to the result under the index of human capital. However, the positive effect is greater under total factor productivity. On long-run results, the findings also showed that all the measures of domestic resource mobilisation influence total factor productivity positively and significantly except direct tax and taxes on international trade. Further analysis on nonlinear effects revealed that there is no human capital laffer curve (HCLC) in the shortrun under the two measures of human capital accumulation. However, there is presence of HCLC in the long-run when total tax, direct, taxes on income, profit, and company gains, and taxes on goods and taxes are considered under the first measure of human capital. On the other hand, we observed the presence of HCLC for direct tax and taxes on goods and services in the long-run under the second measure of human capital. In addition, the results of the net effects indicate that some taxes generate huge revenue to improving the level of human capital development while other tax components can distort human capital development.

Achieving the desired level of human capital accumulation is critical for the development of SSA countries. Evidence has shown that allocation of huge resources plays a significant role in amplifying the accumulation of human capital. In acquiring more education, skills, and knowledge, there is a need for more resources to be devoted so that workers can contribute meaningfully to the production process. Thus, one viable means to sustain human capital accumulation is through domestic resource mobilization. Domestic resource mobilization through taxes has proved to be an effective way for the government to fund public investments such as human capital. More so, taxes make the government to be accountable by investing the resources from taxes in human capital accumulation. Through taxes, people are more involved in how government spends such resources, thus, sustaining the needed resources for accumulation of human capital. This suggests that government (saddled 


\section{Articles}

with the responsibility of effectively and transparently utilized tax revenue) and citizens (payment of tax) are important for the development of human capital in SSA countries.

Exploring domestic resource mobilization to promote human capital accumulation can be done through several policy options. First, designing an effective tax system is very important to address the resource paucity needed for the development of skills, education, and knowledge of workers. However, a poor tax structure may result in low revenue generation due to non-payment of taxes, tax evasion, and avoidance. Second, SSA countries should explore relevant taxes with little or no distortionary effect to ensure sustainable resources for human capital development. For instance, some components of tax (such as taxes on income, profit, and capital gains, and taxes on goods and services) need to be explored by sub-Saharan African countries to augment resources devoted to human capital accumulation. Finally, other facilities that can facilitate tax collection as well as ensure accountability and transparency should be explored by these countries.

\section{References}

Adeniyi, O., Ajayi, P. I., and Adedeji, A.A. (2020). Education and inclusive growth in West Africa. Journal of Economics and Development. https://www.emerald.com/ insight/content/doi/10.1108/JED-04-2020-

Arellano, M. Bond, S. (1991). Some tests of specification for panel data: Monte Carlo evidence and an application to employment equations. Rev. Econ. Stud. 58 (2), 277-297.

Arpaia, A. and Turrini, A. (2008). Government expenditure and economic growth in the EU: long-run tendencies and short-term
Domestic Resource Mobilization and Human Capital

Development in Sub-Saharan Africa

adjustment. European economy papers no. 300

Asongu, S. A. \& Odhiambo, N. M. (2020a). Insurance Policy Thresholds for Economic Growth in Africa. The European Journal of Development, 32, 672-689.

Asongu, S. A. \& Odhiambo, N. M. (2020b). How enhancing gender inclusion affects inequality: Thresholds of complementary policies for sustainable development. Sustainable Development, 28(1), 132-142.

Atems, B. (2015). Another look at tax policy and state economic growth: The long-run and short-run of it. Economics Letters, 127, 64-67.

Barro, R. J. (2013). Education and Economic Growth. Annals of Economics and Finance. 14 (2A), 277-304.

Barro, R.J. (1990). Government Spending in a Simple Model of Economic Growth. Journal of Political Economy, 98, 103-125.

Benos, N. and Zotou, S. (2014). Education and economic growth: A meta-regression analysis. World Development, 64(1), 669-689.

Blackburne, E.F. and Frank, M.W. (2007). Estimation of nonstationary heterogeneous panels. Stata J. 7 (2), 197-208.

Bleaney, M., Gemmell, N. and Kneller, R. (2001). Testing The Endogenous Growth Model: Public Expenditure, Taxation, And Growth Over The Long Run. Canadian Journal of Economics, 4(1), 36-57.

Bloom, D. E., Canning, D. and Sevilla, J. (2004). The effect of health on economic growth: A production function approach. World Development, 32(1), 1-13.

Boateng, A., Asongu, S. A., Akamavi, R., \& Tchamyou, V. S., (2018). Information Asymmetry and Market Power in the African Banking Industry. Journal of Multinational Financial Management, 44, 69-83.

Bovenberg, A. L. and Ewijk, C. V. (1997). Progressive taxes, equity, and human capital 


\section{Articles}

accumulation in an endogenous growth model with overlapping generations. Journal of Public Economics, 64, 153-179

Brambor, T., Clark, W. M., and Golder, M. (2006). Understanding Interaction Models: Improving Empirical Analyses", Political Analysis, 14 (1), 63-82.

Breitung, J. (2001). The local power of some unit root tests for panel data. Emerald Group Publishing Limited.

Chen, G.S., Yao, Y. and Malizard, J. (2017). Does foreign direct investment crowd in or crowd out private domestic investment in China? The effect of entry model. Economic Modelling, 61 (Supplement C), 409-419.

Davies, J. B., Zeng J. and Zhang J. (2000). Consumption vs. income taxes when private human capital investments are imperfectly observable. Journal of Public Economics, 77, 1-28.

Dutta, N., \& Mukherjee, D. (2018). Can financial development enhance transparency?. Economic Change and Restructuring, 51(4), 279-302.

Echevarria, C. A. and Iza, A. (2000). Income Taxation and Finite Horizons in a Human Capital Model. International Tax and Public Finance, 7, 665-689, 2000.

Ehrhart, H., Minea, A., \& Villieu, P. (2014). Debt, seigniorage, and the growth laffer curve in developing countries. Journal of Macroeconomics, 42, 199-210.

Freire-Serén, M. J. and Marti, J. P. (2013) Tax avoidance, human capital accumulation, and economic growth. Economic Modelling, 30, 22-29

Gomez, M. A. (2000). Welfare-maximizing tax structure in a model with human capital. Economics Letters, 68, 95-99

Guo, W. and Clougherty, J. A. (2015). The effectiveness of the state in Chinese outward foreign direct investment: The "go global" policy and state-owned enterprises. Advances in International Management. 28, 141-159.

Gyimah-Brempong, K., and M. Wilson (2004). Health human capital and economic growth in Sub-Saharan African and OECD countries. Quarterly Review of Economics and Finance, 44(1), 296-320.

Gyimah-Brempong, K., Paddison, O., and Mitiku, W. (2006). Higher Education and Economic Growth in Africa. Journal of Development Studies. 42 (3), 509-529.

Hadri, K. (2000). Testing for stationarity in heterogeneous panel data. Econ. J., 3 (2), 148-161.

Harris, R.D., and Tzavalis, E. (1999). Inference for unit roots in dynamic panels where the time dimension is fixed. J. Econ., 91 (2), 201226.

Hartwig, J. (2010). Is health capital formation good for long-term economic growth? -Panel Granger-causality evidence for OECD countries. Journal of Macroeconomics, 32(1), 314-325.

Heckman, J. J., Lochner, L. and Taber, C. (1999). General Equilibrium Treatment Effects: A Study of Tax and Tuition Policy. Fiscal Studies, 20(1), 25-40.

Hendricks, L. (2001). How Do Taxes Affect Human Capital? The Role of Intergenerational Mobility. Review of Economic Dynamics, 4, 695-735.

Ho, S. Y., \& lyke, B. N. (2018). Finance-growthpoverty nexus: a re-assessment of the trickledown hypothesis in China. Economic Change and Restructuring, 51(3), 221-247.

ICTD/UNU-WIDER. (2017). 'Government Revenue Dataset.' Available a https://www. wider.unu.edu/project/governmentrevenuedataset

Im, K.S., Pesaran, M.H. and Shin, Y. (2003). Testing for unit roots in heterogeneous panels. J. Econo. 115 (1), 53-74. 


\section{Articles}

Jacobs, B. and Bovenberg, A. L. (2010). Human capital and optimal positive taxation of capital income. Int Tax Public Finance, 17, 451-478.

Jajri, I. (2007). Determinants of Total Factor Productivity Growth in Malaysia. Journal of Economic Cooperation, 28(3), 41-58.

Kanas, A. and Kouretas, G.P. (2005). A cointegration approach to the lead-lag effect among size-sorted equity portfolio. International Review of Economics and Finance, 14, 181-201

Kaplow, L. (1994). Human capital under an ideal income tax. Virginia Law Review, 80(7), 1477-1514

Kotásková, S.K., Procházka, P., Smutka, L., Maitah, M., Kuzmenko, E., Kopecká, M. and Hönig, V. (2018). The Impact of Education on Economic Growth: The Case of India. Acta Universitatis Agriculturae et Silviculturae Mendelianae Brunensis, 66(1), 0253 - 0262.

Law, S.H., and Habibullah, M.S. (2009). The determinants of financial development: institutions, openness, and financial liberalization. South African J Econ, 77(1):4558.

Levin, A., Lin, C.F. and Chu, C.S.J. (2002). Unit root tests in panel data: asymptotic and nite sample properties. J. Econ. 108 (1), 1-24.

Li, H., and Liang, H. (2010). Health, education, and economic growth in East Asia. Journal of Chinese Economic and Foreign Trade Studies, 3 (2), 110-131.

Li, X. and Liu, X. (2005). Foreign Direct Investment and Economic Growth: An Increasingly Endogenous Relationship. World Development, 33(3), 393-407.

Maddala, G. S., \& Wu, S. (1999). A comparative study of unit root tests with panel data and a new simple test. Oxford Bulletin of Economics and statistics, 61(S1), 631-652.

Michie, J. (2001). The impact of foreign direct investment on human capital enhancement in
Domestic Resource Mobilization and Human Capital

Development in Sub-Saharan Africa

developing countries. Report for the Organization for Economic Co-operation and Development (OECD).

Miller, S. M., and Upadhyay, M. P., (2002). Total Factor Productivity and the Convergence Hypothesis. Journal of Macroeconomics, 24(2), 267-286.

Mohan, G. (2013). Beyond the Enclave: Towards a Critical Political Economy of China and Africa. Development and Change, 44(6), 1255-1272.

Nowak, A.Z. and Dahal, G. (2016). The Contribution of Education to Economic Growth: Evidence from Nepal. International Journal of Economic Sciences, 5(2), 22-41.

Ogundari, K., \& Awokuse, T. (2018). Human capital contribution to economic growth in Sub-Saharan Africa: does health status matter more than education?. Economic Analysis and Policy, 58, 131-140.

Oyinlola, M. A. and Adedeji, A. A. (2020). Enhancing economic growth impact of financial development and human capital through capital flows in sub-Saharan Africa. Journal of Economic Development, 45(2), 95-114.

Oyinlola, M.A. and Adedeji, A. (2019). Human capital, financial sector development, and Inclusive growth in sub-Saharan Africa. Econ Change Restruct., 52(1), 43-66

Oyinlola, M.A. and Adedeji, A.A. (2021). Tax Structure, Human Capital, and Inclusive Growth: Sub-Saharan Africa Perspective. DOI: 10.1002/pa.2670.

Pecorino, P. (1995). Tax rates and tax revenues in a model of growth through human capital accumulation. Journal of Monetary Economics, 36, 527539

Peseran, M.H. (1997). The role of economic theory in modeling long-run. Economic Journal, 107, 178-191.

Peseran, M.H. and Smith, R. (1995). Estimation of Long-run Relationship from Dynamic 
Articles

Heterogeneous Panels. Journal of Econometrics, 68, 79-113

Peseran, M.H., Shin, Y., and Smith, R.P. (1999). Pooled Mean Group Estimation of Dynamic Heterogeneous Panels. Journal of the American Statistical Association, 94(446), 621-634.

Raheem, I. D., Isah, K. O., \& Adedeji, A. A. (2018). Inclusive growth, human capital development, and natural resource rent in SSA. Economic Change and Restructuring, $51,29-48$

Romer, P. M. (1990). Endogenous Technological Change. Journal of Political Economy, 98 (5, Part 2), S71-102.

Schultz, T.W. (1961). Investment in Human Capital. American Economic Review, 51, 1-17. Schultz, T.W. (1971). Investment in Human Capital. New York: Free Press.
Sheffrin, M.S. (2003). Economics: Principles in Action. New Jersey: Pearson Prentice Hall.

Tanzi, V. (1992). Structural factors and tax revenue in developing countries: A decade of evidence. Open Economies. Structural Adjustment and Agriculture, 68, 267-281.

Well, D. N. (2007). Accounting for the effect of health on economic growth. The quarterly journal of economics, 122(3), 1265-1306.

Samans, R., Zahidi, S., \& Leopold, T. A. (2017). The global human capital report 2017: preparing people for the future of work. In World Economic Forum, Geneva, Switzerland.

Zahonogo, P. (2017). Trade and economic growth in developing countries: Evidence from sub-Saharan Africa. Journal of African Trade, 3(1-2), 41-56. 